\title{
Register of New Fruit and Nut Varieties
}

List 40

\author{
Edited by W.R. Okie \\ U.S. Department of Agriculture, Agricultural Research Service, Southeastern Fruit and Tree Nut Research \\ Laboratory, 21 Dunbar Road, Byron, GA 31008
}

Crop Listings': Almond, Apple, Avocado, Black Walnut, Blackberry, Canistel, Carambola, Citrus, Currant, Grape, Jackfruit, Nectarine,
Peach, Pecan, Plum, Raspberry, Strawberry

\section{ALMOND \\ Thomas M. Gradziel \\ Dept. of Pomology, Univ. of California, Davis}

Antoneta.-A late-flowering, self-compatible, and hard-shelled Marcona-type almond. Origin: by J.E. Garcia, J. Egea, F. Dicentra, and T. Berenguer, Murcia, Spain, from a cross between Ferragnes and Tuono. USPPAF ${ }^{2}$. Bloom: $\approx 1$ week later than Nonpareil, 2 days before Ferragnes. Shows small, wrinkled, white petals with a stigma bent toward the anthers at anthesis. Self-compatible and self-pollinating (autogamous) with an average 37\% natural set. Double floral buds commonly producing a high flower density that is greater than the Ferragnes parent. Flowers and twigs are more resistant to Monilinia spp. and frost than Ferragnes parent. Nut: hard shell with very good shell seal with harvest $\approx 15$ days after Nonpareil. Kernel: rounded, Marcona-type, $\approx 25 \mathrm{~mm}$ in length, $17 \mathrm{~mm}$ in width, and $8 \mathrm{~mm}$ thick, and $1.3 \mathrm{~g} / \mathrm{nut}$. About $35 \%$ kernel to nut by weight with low doubles. Tree: very vigorous, spreading tree with a relatively high number of lateral branches on primary scaffolds early in growth. Productive, primarily borne usually on spurs.

Avalon.-California almond type, being a suitable pollinator for both the Nonpareil and Carmel varieties. Origin: USPP 211096 in 1999 by Charles Mancebo, Atwater, Calif., from a chance seedling of unknown parentage. Bloom: $\approx 3$ days earlier than Nonpareil. Each petal has an obtuse tip at the base and a distinctive notch at the apex. Nut: paper-shell that is well sealed, with harvest $\approx 8$ days after the Nonpareil variety and $\approx 6$ to 7 days earlier than the Carmel variety. A thin and prominent wing extends uniformly from the base to the apex. It is considered fairly wide in relative comparison to other varieties. The dorsal fruit suture is relatively shallow but distinct before dehiscence. The immature nut dehisces on the ventral edge only. This is quite clean and distinct. In many nuts, the hull pulls away with the outer shell layer still attached to the inner hull. Kernel: medium size as compared to other varieties, and being $\approx 21 \mathrm{~mm}$ in length, $12 \mathrm{~mm}$ in width, and $9 \mathrm{~mm}$ thick. The kernel is darker and more oval than that produced by the Nonpareil with $\approx 64 \%$ shelling percentage. Tree: average in size and vigor, smaller and having a much more upright growth habit when compared to Nonpareil. Productive, cropping predominantly from short and stubby spurs that are 2 years old or older

Garden Princess.-Self-fertile almond with small size tree, upright in growth, being a regular and productive bearer of medium size, soft shell, sweet kernel almonds. Origin: USPP 5146 in 1983 by Chris F. Zaiger, Modesto, Calif. From the cross [(Merced x genetic dwarf peach seedling with double red flowers) selfed]. Bloom: dark pink bloom $\approx 4$ to 5 days after Merced. Nut: paper shell with harvest approximately with Mission. Kernel: $\approx 19 \mathrm{~mm}$ in length, $11 \mathrm{~mm}$ in width, and $8 \mathrm{~mm}$ thick. About $58 \%$ kernel to nut by weight. Tree: leaf glands: 2-4 (usually two) and alternate, primarily on petiole. Nuts borne usually on spurs though also with production on shoots.

Kahl.-Medium size, upright tree with well-sealed nuts. Origin: USPP 9282 in 1995 by Marvin Kahl, Merced, Calif. Chance seedling in a Nonpareil, Davey, and Mission planting. Bloom: blooming $\approx 3$

\footnotetext{
${ }^{1}$ Thanks to the crop editors for compiling this information. Individuals with varieties to describe should contact the crop editors directly. Individuals willing to serve as crop editors should contact W.R.O.

${ }^{2}$ USPPAF $=$ U.S. Plant Patent Applied For; USPP = U.S. Plant Patent.
}

days later than Nonpareil, having a pink instead of white blossom. Nut: semi-hard shell with good shell seal but a moderate number of blanks and with harvest being $\approx 14$ days after Nonpareil. Kernel: large, flat kernels $\approx 28 \mathrm{~mm}$ in length, $13 \mathrm{~mm}$ in width, and $8 \mathrm{~mm}$ thick with $\approx 1.1 \mathrm{~g} /$ nut. About $44 \%$ kernel to nut by weight. Moderate to numerous doubles. Crop moderate, borne mostly on spurs with some on shoots and close to larger branches.

Marta.-A late-flowering, self-compatible, and hard-shelled Desmayo Largueta-type almond. Origin: by J.E. Garcia, J. Egea, F. Dicentra, and T. Berenguer, Murcia, Spain, from a cross between Ferragnes and Tuono. Patent pending. Bloom: $\approx 2$ days later than Nonpareil, 6 days before Ferragnes. Shows large, smooth, white petals with a straight stigma ending at anther height at anthesis. Selfcompatible and partially self-pollinating (autogamous) with an average $28 \%$ natural set. Double floral buds commonly producing a high flower density that is greater than the Ferragnes parent. Flowers and twigs are more resistant to Monilinia spp. and frost than Ferragnes parent. Nut: hard shell with very good shell seal with harvest approximately with Nonpareil. Kernel: elongated, Desmayo Largueta type, $\approx 26 \mathrm{~mm}$ in length, $15 \mathrm{~mm}$ in width, and $9 \mathrm{~mm}$ thick and $1.4 \mathrm{~g} / \mathrm{nut}$. About $32 \%$ kernel to nut by weight with low doubles. Tree: very vigorous, upright tree with relatively few lateral branches on primary scaffolds early in growth. Productive, nuts primarily borne on spurs.

Morley.-Very late blooming Butte-type almond with good vigor and moderately dense foliage. Origin: USPP 8269 in 1993 by Lowell G. Bradford and Norman G. Bradford, Le Grand, Calif. From a cross of Mission (Texas) to an unnamed late blooming almond seedling as pollen parent. Bloom: $\approx 2$ weeks later than Nonpareil, 1 week later than Mission (Texas). Nut: semi-hard shell with good shell seal but moderate blanks with harvest $\approx 14$ days after Nonpareil. Kernel: dark, medium-sized Butte type. About $22 \mathrm{~mm}$ in length, $13 \mathrm{~mm}$ in width, and $8 \mathrm{~mm}$ thick and $1.2 \mathrm{~g} / \mathrm{nut}$. About $56.4 \% \mathrm{kernel}$ to nut by weight. Tree: vigorous, large and somewhat upright. Leaf glands globose, averaging 4 to 6 per leaf, mostly oppositely positioned on petiole and base of blade. Borne usually on spurs though with considerable production on shoots, often on smaller fruiting wood.

Ne Plus Ultra.-A very old and very early-blooming almond still used for pollination of Nonpareil early bloom. Origin: Selected by A.T. Hatch in 1879 from open-pollinated seed thought to be from the Lanquedoc region of France. Bloom: $\approx 5-7$ days before Nonpareil and thus susceptible to frost. Nut: large nut with well-sealed paper shell and harvest $\approx 14$ days after Nonpareil. Kernel: large, often with a high percentage of doubles. Tree: medium size with spreading, somewhat willowy growth habit. Crops moderate, sometimes showing precocious bearing on long, previous-season shoots followed by heavy spur production.

Peerless.-An old, early-blooming almond still planted as an early-season pollinizer for Nonpareil bloom and sold primarily to the in-shell market. Origin: selected before 1900 by Wilson Treat of Davis, Calif., from unknown origins. Bloom: $\approx 3-5$ days before Nonpareil and thus susceptible to frost. Nut: large, light colored, with a hard and well-sealed shell, harvested $\approx 10$ days after Nonpareil. Moderate crop, with a tendancy to drop nuts prematurely. Kernel: medium size and quality. Tree: medium size, medium to spreading in growth habit and occasionally showing moderate to severe noninfectious bud failure.

Rosetta.-Early-blooming, Nonpareil-type almond used as a pollinizer for the early Nonpareil bloom. Origin: USPP 8236 in 1993 
by William Spoto, Yuba City, Calif., from an almond chance seedling found in an almond seedling rootstock orchard of Nonpareil and Drake that had been planted in the early 1900s. Bloom: $\approx 3$ days before Nonpareil. Nut: medium to large size with moderate shell seal and harvest just after Nonpareil. The suture of the shell has a wing more prominent than that of Nonpareil. Kernel: Nonpareil type but larger. About $27 \mathrm{~mm}$ in length, $14 \mathrm{~mm}$ in width, and $9 \mathrm{~mm}$ thick and $1.3 \mathrm{~g} /$ kernel. About $51 \%$ kernel to nut by weight. Tree: upright in structure. Leaf glands globose, averaging 2 per leaf, mostly alternately positioned on petiole and base of blade. Crop borne usually on spurs though with considerable production on shoots, often on smaller fruiting wood.

Savana.-Very late-blooming, Nonpareil-type almond with moderate vigor. Origin: USPP 8270 in 1993 by Lowell G. Bradford and Norman G. Bradford, Le Grand, Calif., from cross of Nonpareil to an unnamed late-blooming almond seedling as pollen parent. Bloom: $\approx 2$ weeks after Nonpareil and 1 week later than Mission (Texas). Nut: Nonpareil type with very good shell seal and harvest $\approx 2$ weeks after Nonpareil and 2 weeks earlier than Mission (Texas). Kernel: Nonpareil type with large, flat, light-colored seed, $\approx 25 \mathrm{~mm}$ in length, $12 \mathrm{~mm}$ in width, and $7 \mathrm{~mm}$ thick and $1.2 \mathrm{~g} /$ nut. About $61.6 \%$ kernel to nut by weight. Tree: medium in size moderately vigorous and spreading in growth. Crop borne almost entirely on spurs and on all sizes of wood. Leaf glands globose, mostly 2 or 3 per leaf being alternately positioned on petiole and base of blade.

Valenta.-Semi-hard shell seedling almond. Origin: USPP 4885 in 1982 by Frank E. Valenta, Delhi, Calif., as a chance seedling. Bloom: blooms white during period $\approx 2$ weeks earlier than Thompson and $\approx 2$ days after the Nonpareil. Nut: semi-hard shell with moderate shell seal with harvest period after the Thompson and Nonpareil and approximately with the Merced variety. Kernel: $\approx 21 \mathrm{~mm}$ in length, 11 $\mathrm{mm}$ in width, and $8 \mathrm{~mm}$ thick and $1.1 \mathrm{~g} /$ nut. About $56 \%$ kernel to nut by weight. Medium size, sweet kernels of good quality. Tree: large, spreading, dense, and vigorous; abundantly foliated with small, lanceolate, acutely pointed leaves having a finely serrate margin, and small, green, alternate, globose glands. Consistent bearer of small, well-sealed nuts.

\section{APPLE \\ Robert A. Norton AppleCorps East Wenatchee, Wash.}

A5510.-See Snapp Stayman.

Adams Apple (Burchinal).—An extremely early-coloring strain of Red Delicious. Origin: limb mutation of Oregon Spur Delicious, discovered Sept. 1993 in Othello, Wash., by Robert Burchinal; introd. 1999 by Van Well Nursery, Wenatchee, Wash. USPPAF. Fruit: develops $100 \%$ red color at fruit set, with darker red color than its parent throughout its development; otherwise, similar to parent in all respects. Tree: upright, spur type, similar to parent.

Autumn Gala (Harry Black Gala).-A late-maturing sport of Gala. Origin: limb sport of Kidds D-8 Gala, found at Catoctin Mountain Orchard, Thurmont, Md., in 1992 by Bob Black. Introd. 1999; assigned to International Plant Management, Inc., Lawrence, Mich. USPPAF. Fruit: typical size, shape, and quality of Kidds D-8, maturing 6 weeks later than the parent; flesh much firmer than parent's, 18-23 pounds at maturity. Tree: same as parent. Recommended for fresh market in warmer climates where regular Gala matures too soon.

Auvil Early Fuji (Fuji 216).-Strain of Fuji ripening 3-4 weeks earlier than standard Fuji. Origin: limb mutation of TAC 114 Fuji; discovered Sept. 1993 at Vantage, Wash. Introd. 1998; assigned to Van Well Nursery, Wenatchee, Wash. USPP 10141. Fruit: $90 \%$ to 95\% pink-red skin over yellow ground color; flesh texture, color, and flavor similar to parent's, but maturity is 145-150 days from full bloom, 3-4 weeks earlier than TAC 114 Fuji or standard Fuji. Tree: similar to standard Fuji, but with less vigor than parent.
Bull McIntosh.-See LindaMac.

Burchinal.-See Adams Apple.

Co-op 25.-See Scarlet O'Hara.

Crown Empire.-Empire mutation suited to the Northeast. Origin: limb sport of Empire, discovered in 1993 by Jeff Crist, Walden, N.Y. USPPAF. Assigned to Adams County Nursery, Aspers, Pa. Fruit: full red blush color develops 10 days ahead of Empire. Tree: same as Empire.

Del Red Rome.-A nonbleeding mutation of Red Rome Beauty. Origin: discovered 1990 by Del Nanney in Dana, N.C., as a whole-tree mutation of Barkley Red Rome. Fruit: similar to Barkley, but the skin has a darker stripe over the blush-red color; more significant is that the skin color does not bleed into the flesh as occurs with Law Red Rome. This is important for processing. Tree: similar to Barkley Red Rome.

Fuji 216.-See Auvil Early Fuji.

Harry Black Gala.-See Autumn Gala.

Harten Mac.-See Scotian Spur Mac.

LindaMac (Bull McIntosh). - An early-coloring red mutation of Redmax. Origin: whole-tree mutation of Redmax found in 1997 in the orchard of Leslie and Linda Bull, Casnovia, Mich. Released Fall 1999; assigned to International Plant Management, Inc., Lawrence, Mich. USPPAF. Fruit: medium to large, round, short stem, 100\% red blush with typical McIntosh texture and flavor. Maturity with Redmax. Tree: very vigorous, upright, precocious; otherwise same as parent.

Scarlet O'Hara (Co-op 25)._-A high-quality, scab-resistant introduction from Purdue, Rutgers and Illinois (PRI) . Origin: PCFW2134 X PRI669-205, cross made at NJAES in 1971, screened for scab resistance at Purdue and designated CLR 20T41. Seedling selected by E.W. Williams in 1978, released as Coop 25 in 1984 and named in 1999 by J. Janick, J.C.Goffreda, and S.S. Korban. USPPAF. Fruit: bright red skin, blocky shape, large size; flavor mildly rich, very crisp and firm, ripening mid-September, 1 week before Delicious. Quality best after 1-2 months storage; storage life over 7 months at $1{ }^{\circ} \mathrm{C}$ regular storage. Though resistant to scab, it is susceptible to fireblight and moldy core. Tree: moderately spreading and very productive; similar to Rome Beauty.

Scotian Spur Mac (Harten Mac).-A spur strain of McIntosh, with excellent color and size. Origin: limb mutation from top of 80year-old standard McIntosh discovered in Waterville, Nova Scotia, in 1994 by Jacob Hartenhof. USPP 10070. Assigned to Adams County Nursery, Aspers, Pa. Introd. 1998. Fruit: typical McIntosh size and shape, with improved color. Tree: uniform compact spur-type character, upright in growth, and $60 \%$ the size of conventional McIntosh.

Snapp Stayman (A5510)._-Improved red strain of Red Stayman. Origin: discovered in 1989 by Alfred Snapp, Winchester, Va., as a limb mutation of Red Stayman 201. USPP 11071. Assigned to Adams County Nursery, Aspers, Pa.; introd. 1997. Fruit: similar to its parent, except with a deeper red color intensity and finish. Tree: same as Red Stayman.

Tex Red Winesap.-Higher-colored mutation of Red Winesap. Origin: discovered in 1985 by John Ford, Malaga, Wash. Whole-tree mutation of Ruble Red Winesap. Fruit: similar to Ruble Red Winesap except for higher skin color. Tree: identical to Red Winesap.

\section{AVOCADO}

Robert J. Knight, Jr.

Univ. of Florida, Tropical Research and Education Center Homestead

Murashige.-Guatemalan well adapted to Hawaii. Origin: Hawaii. Fruit: heavy bearer with dark green pyriform fruit, rough thick skin. Weight 450-550 g. Pulp moisture 71\%, 20\% oil, edible portion $65 \%$ to $71 \%$, internal color light yellow; mild to nutty flavor, spring and summer production. Seed small. Tree: B flowering type.

Yamagata.-Guatemalan with a weight of 450 g. Origin: Orig. in Hawaii. Fruit: Pulp moisture $65 \%, 23 \%$ oil, edible portion $66 \%$, fibrous with strong nutty flavor. Tough gritty skin, fruit with curved neck. Susceptible to postharvest diseases. Tree: B flowering type. 


\section{BLACK WALNUT}

\section{William Reid \\ Pecan Experiment Field, Kansas State Univ. Chetopa}

Dubois 8201.-See McGinnis

HPC-120.-A large-fruited, productive, black walnut cultivar. Origin: seedling originating from the Missouri State Forest Nursery, Licking, Mo., and established in a walnut plantation in Cedar Co., Mo. Selected by James E. Jones, Hammons Products Co., Stockton, Mo. USPP 9925 granted in 1997. Nut: large, oblate nut weighs $21 \mathrm{~g}$ and contains 20\% kernel. Tree: precocious. Fruit borne on spurs. Protogyno us flowering habit. Moderately resistant to anthracnose.

HPC-148. - A consistently-bearing black walnut cultivar. Origin: seedling originating from the Missouri State Forest Nursery, Licking, Mo., and established in a walnut plantation in Cedar Co., Mo. Selected by James E. Jones, Hammons Products Co., Stockton, Mo. USPP 9925 granted in 1997. Nut: medium-sized, elliptical nut weighs $16 \mathrm{~g}$ and contains $26 \%$ kernel. Tree: precocious. Fruit borne on spurs. Protandrous flowering habit. Good resistance to anthracnose.

McGinnis (Dubois 8201). - A medium-sized, thinned-shelled black walnut cultivar. Origin: native selection discovered by Joe McGinnis on his Richardson Co., Neb., farm. First propagated by Robert Dubois of Burlington, Kans., in 1977. Nut: small, oblate nut weighs $14 \mathrm{~g}$ and yields $33 \%$ kernel. Excellent cracking quality. Kernel is light colored and high quality. Tree: fruit borne on spurs. Recommended in $\mathrm{Ne}-$ braska.

Rupert.-A small black walnut cultivar with outstanding kernel quality. Origin: seedling selection found within the City of Chetopa, Kans., on property owned by James Rupert. Selected by W. Reid, Kansas State Univ. Nut: small, very widely-ovate nut weighs $15 \mathrm{~g}$ and contains $27 \%$ kernel. Cracks well releasing light colored kernels in large pieces. Kernel quality outstanding. Tree: precocious. Fruit borne on spurs. Good resistance to anthracnose. Recommended in Kansas.

STW-13.-A consistently bearing black walnut cultivar. Origin: seedling originating from the Missouri State Forest Nursery, Licking, Mo., and established in a walnut plantation in Green Co., Mo. Selected by James E. Jones, Hammons Products Co., Stockton, Mo. USPP 9924 granted in 1997. Nut: small, round nut weighs $15 \mathrm{~g}$ and contains $26 \%$ kernel. Tree: not precocious. Fruit borne on spurs. Protandrous flowering habit. Moderately resistant to anthracnose.

\section{BLACKBERRIES AND HYBRID BERRIES}

\section{Chad E. Finn \\ USDA-ARS, Northwest Center for Small Fruit Research Corvallis, Ore.}

John R. Clark

Univ. of Arkansas, Fayetteville

Apache.-An erect, thornless, large-fruited, high-quality blackberry for fresh market. Origin: Fayetteville, Ark., by J.R. Clark and J.N. Moore, Univ. of Arkansas. Ark. 1007 x Navaho; cross made in 1988; selected in 1991; tested as Ark. 1798; introd. in 1999. USPP pending. Fruit: very large $(8-10 \mathrm{~g})$; firm, but do not store as well as Navaho but superior in storage compared to Shawnee; attractive and glossy; excellent flavor; soluble solids $10.7 \%$; fresh seed weight 12.6 $\mathrm{mg}$; ripens 5 days after Navaho. Plant: erect canes; vigorous; thornless; productive, exceeding that of Arapaho or Navaho; blooms 2-3 days before Navaho; winter hardy in trials in Arkansas; moderately resistant to anthracnose (Elsinoe veneta); reaction to rosette (Cercosporella rubi) and orange rust (Gymnoconia nitens) is unknown.

Chickasaw.-An erect, thorny, large-fruited, high-quality blackberry for fresh market. Origin: Fayetteville, Ark., by J.R. Clark and J.N. Moore, Univ. of Arkansas. Ark. 842 x Ark. 1246; cross made in 1985; selected in 1988; tested as Ark. 1647; introd. in 1999. USPP pending. Fruit: very large ( $8-11 \mathrm{~g})$; long and cylindrical; firm, but do not store as well as Navaho but improved in storage compared to
Shawnee; attractive and glossy; excellent flavor; soluble solids 9.6\%; fresh seed weight $9.1 \mathrm{mg}$; ripens 3 days later than Shawnee. Plant: erect canes; vigorous; thorny; very productive, exceeding that of Shawnee in some trials; blooms 4 days before Shawnee; winter hardy in trials in Arkansas; moderately resistant to anthracnose; reaction to rosette and orange rust is unknown.

\section{CANISTEL}

Robert J. Knight, Jr.

\section{Univ. of Florida, Tropical Research and Education Center} Homestead

Bruce.-Poor-quality variety. Origin: south Florida. Fruit: large, uniform, and attractive with a favorable pulp to seed ratio (17.4). Eating quality is rated inferior because of the dry, mealy flesh with little aroma. Fruit weight averages $375 \mathrm{~g}$ (range 185-675), with seed number averaging 1.8 (range $1-4$ ), and seed weight averaging $12 \mathrm{~g}$. Tree: production is concentrated during middle to late summer (August-October) and winter (February-March) and has been lighter than TREC 9680.

Fairchild 1.-Variety with attractive, pleasant-tasting fruit. Origin: South Florida. Fruit: shape and size are irregular, with an average weight of $296 \mathrm{~g}$ (range 120-365), an average of 1.7 seed (range 1-3) per fruit and an average seed weight of $12 \mathrm{~g}$. Fruit/seed ratio is 17.4. Most fruit are attractive and pleasant-flavored, with moist soft pulp but a strong, unpleasant aroma. Production is concentrated in late summer (September-October) with smaller crops in winter and spring, and is lighter than that of Bruce or TREC 9680. Tree: upright and smaller than most other canistel selections, and can be maintained at a height of $3.5 \mathrm{~m}$ and a spread of $3 \mathrm{~m}$ with a single winter pruning.

Fairchild 2.-Excellent-flavored variety for Florida. Origin: South Florida. Fruit: shape and size are more irregular than Fairchild 1, with a typical curved appearance. Fruit weight averages $161 \mathrm{~g}$ (range 60255 ), an average of 2.1 seed (range 1-4) per fruit and an average seed weight of $11 \mathrm{~g}$. Fruit/seed ratio is 6.7. Pulp is moist and considered among the best flavored by many in Florida. The aroma is usually weak. Tree: upright with moderate vigor and light, irregular production spread throughout the year.

Fitzpatrick.-Variety with small, attractive fruit. Origin: South Florida, at the Tropical Research and Education Center of the Univ. of Florida, Homestead. Fruit: uniformly small and attractive (average weight $70 \mathrm{~g}$, range 44-96), with a greenish yellow color at maturity, with moist, sweet flesh of good quality. The aroma is strong and objectionable. Seed average 1.4 per fruit (range 1-3) and average seed weight is $6.9 \mathrm{~g}$. Fruit/seed ratio is 7.2. Fruit of this type is common throughout the Caribbean region. Tree: upright and compact with small, distinctive leaves. Production is heavy and concentrated in fall and winter (September-January).

Kiesau.-Dry-fleshed variety. Origin: South Florida, at the home of Don Kiesau, South Miami. Fruit: medium-sized (weight $253 \mathrm{~g}$, range 192-322) with an average seed number of 2.8 (range 1-4) and average seed weight of $12.5 \mathrm{~g}$ and a fruit/seed ratio of 7.2. Fruit has a distinctive shape, similar to TREC 9681 but more elongated, and rather dry flesh. Tree: moderately vigorous and open, requiring one pruning per year to maintain a height and spread of $3.5 \mathrm{~m}$. Production is heavy, with the main season in the winter months.

Ross.-Considered by some to belong to a different species than other canistel cultivars. Origin: Costa Rica. Fruit: size is highly variable (average weight $121 \mathrm{~g}$, range 75-160) and flesh is moist and sweet. Average number of seed per fruit is 1.6 (range 1-3), average seed weight is $3.5 \mathrm{~g}$ and fruit/seed ratio is 21.6. Tree: slower-growing than other canistels and requires one light pruning per year to maintain a height of $3.5 \mathrm{~m}$ and a spread of $2 \mathrm{~m}$. It is often sparsely foliated, leading to fruit sunburning. Production is medium to heavy and concentrated in the fall and winter months.

TREC 9680.-A large-fruited productive variety. Origin: South Florida, Univ. of Florida Center, Homestead. This is one of the most attractive selections due to its size, shape, and color. Fruit: weight averages $395 \mathrm{~g}$ (range 190-715) with an average of 1.7 seed (range 14) weighing $12 \mathrm{~g}$ and a fruit/seed ratio of 19.4. Fruit is large and uniform but dry and mealy in some years. Tree: vigorous and spread- 
ing, requiring pruning twice a year to maintain a height and spread of $4 \mathrm{~m}$. Production is extremely heavy and concentrated in early fall (September-October) or early spring (February-April).

USDA 1.-Dry-fleshed variety. Origin: South Florida, USDA Clonal Repository at Miami. Fruit: flesh is dry and mealy with a large number of seeds (average 3.2, range 1-5), an average seed weight of $11 \mathrm{~g}$ and a fruit/seed ratio of 6.4. Tree: slow upright growth and requires only one pruning per year to keep it at a height of $3.5 \mathrm{~m}$ and a spread of $2 \mathrm{~m}$. Production is irregular and light.

\section{CARAMBOLA}

\section{Robert J. Knight, Jr. \\ Univ. of Florida, Tropical Research and Education Center, Homestead}

Dah Pon.- Variety not widely planted in Florida. Origin: in Taiwan, introd. to U.S. by USDA. Fruit: small to medium-sized, pale yellow (near-white), with low acid content and medium sugar content, flavor mild to insipid.

Kajang.-Variety grown to some extent in home gardens and germplasm collections in south Florida. Origin: Malaysia. Fruit: medium-large, yellowish-orange to orange in color, with high sugar and medium acid content.

Maha.-Variety grown to some extent in home gardens and germplasm collections in Florida. Origin: Malaysia. Fruit: large, pale yellow in color, with medium sugar and low acid content.

Sri Kembangan.- - The seed parent of Kary. Origin: Malaysia, introd. to Hawaii by R.A. Hamilton and from there to Florida. Fruit: medium-large, yellowish-orange to orange in color, with high sugar and medium acid content, of very good quality. Not a high producer but kept in some home gardens because of the value of the fruit. Flowers short-styled.

Tean Ma._-Variety not widely planted in Florida. Origin: Taiwan, introd. to U.S. and released here by USDA. Fruit: medium-sized and medium-yellow in color, with medium sugar and low acid content, of mild to insipid taste.

Thai Knight.-Variety grown in some home gardens in Florida. Origin: Florida from seed of Malaysian origin grown by Capt. Laine Guthrie, an airline pilot and fruit grower. Fruit: medium size, yellowish-orange to orange in color, with high sugar and medium acid content.

\section{CITRUS}

\section{Eliezer S. Louzada Texas A\&M Univ., Kingsville Citrus Center, Weslaco}

Ariake.-A new tangor variety. Origin: Cross-pollination of Seike navel orange as a seed parent and Clementine mandarin as the pollen parent. USPP 9235 issued 8 Aug. 1995 to Fruit Tree Research Station, Ministry of Agriculture, Japan. Fruit: round, rind surface smooth with deep orange color and peeling characteristics slightly inferior to that of Clementine; flesh is deep orange, juicy, very sweet, low acid and moderate flavor, produce a few monoembryonic seeds. Tree: moderate vigor with spreading habit.

Mor.-A late mandarin variety containing few seeds. Origin: obtained by gamma radiation of buds of Murcott tangor in 1985. USPP 8378 issued 14 Sept. 1993 to the State of Israel, Ministry of Agriculture. Fruit: oblate, medium size, moderate depressed stalk end and a truncate distal end; surface is smooth with a yellow orange color. Albedo is white and the flesh is orange with 9-11 segments, very juicy and contains 2-7 seeds. Tree: short and compact.

Nadorcott.-A tangerine variety, seedless under self-pollination. Origin: nucellar selection from a chance cross-pollination possibly between Murcott as a seed parent and a unknown pollen parent discovered by El Bachir Nadori. USPP 10480 issued 7 July 1998, to Jean de Maistre, France. Fruit: oblate with base and apex slightly depressed; rind surface is smooth and orange red color with medium adherence to the flesh; very juicy with an attractive aroma and an excellent flavor; flesh is deep orange with $8-13$ segments. Tree: very vigorous.
Rishon.-Very early-fruit-ripening mandarin. Origin: controlled pollination between the seed parent Temple and the pollen parent Michal performed in 1978 at the Agricultural Research Organization, The Volcani Center, Israel. USPP 8377 issued 14 Sept. 1993, to the State of Israel, Ministry of Agriculture, Agricultural Research. Fruit: oblate to rounded, small to medium size, short necked or evenly rounded basal end and a depressed distal end; the rind is thin and weakly adherent to the flesh; the color of the albedo is white and the flesh is orange; the fruit contains from 5-9 polyembryonic seeds, fruit reaches maturity in late September or early October in Israel. Tree: medium size.

Winola.-Seedless mandarin variety. Origin: resulted from a cross pollination between Wilking as a seed parent and Minneola as a pollen parent performed at the Agricultural Research Organization, The Volcani Center, State of Israel. USPP 8219 issued 4 May 1993, to the State of Israel, Agricultural Research Organization. Fruit: Globose, medium size, surface is wrinkled with an orange-red color, no areola or navel; adherence of the flesh to the rind varies from strong to semi-adherent to easy peeling depending on rootstock and fruit maturity; flesh is juicy, aromatic and of excellent taste; the segments of the fruit are easily separated and the fruits are typically seedless. Tree: small to medium size.

\section{CURRANT}

\section{Kim E. Hummer \\ USDA-ARS National Clonal Germplasm Repository, Corvallis, Ore.}

Kristin.-Early-flowering, vigorous black currant for fresh-fruit market. Origin: developed at the Dept. of Horticulture and Crop Sciences, Agricultural Univ. of Norway, As, Norway, by Johannes Oydvin. Ben Tron x (Hedda x E.M. 1428/70). Cross made in 1986, introduced in 1990. Fruit: medium firm, large fruits on fairly long strigs; low in acid, high in sugar, suitable for hand-picking and less suitable for mechanical harvest. The fruit quality is maintained in the persistent clusters for a long time. Fruit clusters are well suited to freezing. Good productivity. Plant: vigorous, fairly erect plant for home gardeners. Early flowering and early-midseason ripening. Recommended for growing in southern Norway to the Netherlands. Resistant to powdery mildew and leaf spot. Susceptible to black currant gall mite and white pine blister rust.

Narve Viking.-Late-flowering black currant cultivar suited to mechanical harvesting. Origin: developed at the Dept. of Horticulture and Crop Sciences, Agricultural Univ. of Norway, As, Norway, by Johannes Oydvin. Ben Tron x SCRI C2/1/62. Cross made in 1991; introduced in 1997. Norwegian plant breeding rights. Fruit: mediumsized on medium length clusters with very good productivity. Firm fruit, fairly tough skin. Moderate acid with a fairly good fresh fruit taste that has high juice color and high ascorbic acid. Very high-quality juice production. Plant: vigorous, stout, very erect branching habit, suitable for mechanical harvesting; late flowering and ripening seasons. Recommended for growing in Southern Norway to the Netherlands. Resistant to powdery mildew and leaf spot; susceptible to white pine blister rust.

\section{GRAPE}

John R. Clark

Univ. of Arkansas, Fayetteville

Jupiter.-A large-fruited, mild muscat, seedless, blue table grape. Origin: orig. in Fayetteville, Ark., by J.R. Clark and J.N. Moore, Univ. of Ark. From the cross Ark.1258 x Ark.1672; cross made in 1981; sel. in 1984; tested as Ark.1985; introd. in 1999. USPPAF. Fruit: blue; oval to slightly oblong; seedless with small seed traces observed in some years but not noticeable in eating; large (5 g); soluble solids $19.8 \%$; mild muscat flavor and rated excellent; nonslipskin and semicrisp texture; no skin cracking observed; ripens 5 days later than Venus but 5 days earlier than Reliance. Cluster: conical with occasional shoulder; well-filled but not excessively tight; medium-large (250 g). Vine: medium vigor; productive; hardiness moderate, similar to 
Suffolk Red and hardier than Einset Seedless, Marquis, and Venus, but less hardy than Mars and Reliance; moderate resistance to black rot, powdery mildew, and anthracnose and similar in susceptibility to downy mildew as Venus; commercial fungicide spray program for eastern U.S. grapes recommended for reliable production; recommended where other eastern U.S. table grape cultivars are adapted.

Melissa.-A large-fruited, midseason, seedless, white table grape. Origin: orig. in Fresno, Calif., by D.W. Ramming and R. Tarailo, USDA Horticultural Crops Research Laboratory. Crimson Seedless $\mathrm{X}$ B40-208, with embryo rescue used to produce seedlings; cross made in 1988; sel. in 1991; tested as C45-59; introd. in 1999; not patented. Fruit: white; seedless with one to two aborted seeds that are very small and unnoticeable; large (naturally 5-6 g) and responds to gibberellic acid at bloom and berry set but requires rates lower than those for Thompson Seedless, and gibberellic acid application plus girdling can increase berry weight by $1 \mathrm{~g}$; flavor sweet with mild muscat when fruit is very ripe and exposed to light; nonslipskin and medium skin thickness; ripens at the end of Thompson Seedless season at Fresno. Cluster: conical with shoulder; loose to well filled; large, 320-544 g. Vine: vigorous, and a large trellis may be needed to manage vigor and light penetration; productive when cane pruned; blooms 1-2 days before Thompson Seedless.

Neptune.-A seedless, white table grape. Origin: orig. in Fayetteville, Ark., by J.R. Clark and J.N. Moore, Univ. of Ark. Cross of Ark.1562 x Ark.1704; cross made in 1985; sel. in 1988; tested as Ark.2083; introd. in 1999. USPPAF. Fruit: white; elliptic to slightly ovate; seedless with small seed traces observed in some years but not noticeable in eating; medium ( $2.5 \mathrm{~g})$; soluble solids $19.7 \%$; flavor a fruity semi-American grape flavor but not of same character as $V$. labrusca; nonslipskin; no skin cracking observed; ripens 7 days later than Reliance. Cluster: conical, often with a small shoulder; well filled; large (345 g). Vine: low to medium vigor and less procumbent in shoot growth than many eastern U.S table cultivars; productive; hardiness moderate, probably similar to Venus; moderate resistance to black rot, powdery mildew and anthracnose and similar in susceptibility to downy mildew as Venus; commercial fungicide spray program for eastern U.S. grapes recommended for reliable production; recommended where other eastern U.S. table grape cultivars are adapted.

Orion.-White, Müller-Thurgau-type wine grape resistant to downy mildew. Origin: orig. in Siebeldingen, Germany, at the Institute for Grapevine Breeding Geilweilerhof. Optima x Villard Blanc; tested as Gf.Ga-58-30; introd. in 1994. Variety protection in Germany. Fruit: white; size similar to Müller-Thurgau and Riesling; ripens with Müller-Thurgau; wines are aromatic, fresh and similar to MüllerThurgau; Cluster: loose; medium to large. Vine: vigorous and semidrooping shoot growth can require more summer pruning than some cultivars; productive; wood maturity good; sufficiently resistant to downy mildew and control measures not required at the location of this cultivar's development; resistance to powdery mildew sufficient also but sulfur application may be needed in some years.

Phoenix.-White, light-muscat wine grape resistant to downy and powdery mildews. Origin: orig. in Siebeldingen, Germany, at the Institute for Grapevine Breeding Geilweilerhof. Bacchus X Villard Blanc; tested as Gf.Ga-49-22; introd. in 1992. Variety protection in Germany. Fruit: white; size larger than Müller-Thurgau; ripens with Müller-Thurgau; berry prone to splitting when heavy rainfalls occur near harvest; wines are light muscat in flavor. Cluster: more compact than Müller-Thurgau but similar in size. Vine: medium to high vigor; yields similar to Müller-Thurgau but higher than Riesling; excellent wood maturity contributes to high winter hardiness; good resistance to downy and powdery mildews and control measures are normally not necessary at the location of this cultivar's development.

Regent.-Blue wine grape resistant to downy mildew. Origin: orig. in Siebeldingen, Germany, at the Institute for Grapevine Breeding Geilweilerhof. (Silvaner X Müller-Thurgau) x Chambourcin; tested as Gf.67-198-3; introd. in 1994. Variety protection in Germany. Fruit: blue; size small and similar to Pinot Noir; ripens with or just before Portugieser; berry drop can occur at advanced stages of ripeness; wines are full-bodied. Cluster: medium; less compact than Pinot Noir. Vine: medium vigor; yields similar to Pinot Noir; highly resistant to downy mildew and resistant to powdery mildew and control measures are normally not necessary with the exception of an application of sulfur at sites with high powdery mildew pressure.

Scarlett.-A large-fruited, pistillate, red muscadine cultivar for fresh market. Origin: orig. in Griffin, Ga., by R. Lane, Univ. of Georgia. Summit X Triumph; cross made in 1981; selected in 1986; tested as GA 35-9-1; introd. in 1998. USPPAF. Fruit: slightly elongated; red; large $(11 \mathrm{~g})$; soluble solids $17.3 \%$; free-run juice $\mathrm{pH} 3.4$; flavor rated very good, exceeding that of either parent or Fry; seeds average 3.3/berry; $78 \%$ of berries have a closed abscission layer at harvest. Cluster: five to seven berries/cluster. Vine: pistillate; vigorous; productive; tolerant to ripe rot and bitter rot.

Sirius.-White wine grape resistant to downy and powdery mildews. Origin: orig. in Siebeldingen, Germany at the Institute for Grapevine Breeding Geilweilerhof. Bacchus X Villard Blanc; tested as Gf.Ga-57-27; introd. in 1995. Variety protection in Germany. Fruit: white; large; ripens between Müller-Thurgau and Silvaner; wines are full-bodied with a pleasant, fruity bouquet. Cluster: large and more shouldered than Müller-Thurgau. Vine: vigorous; yields similar to Müller-Thurgau; highly resistant to downy mildew and resistant to powdery mildew and control measures are normally not necessary; wood maturity and winter hardiness similar to Riesling.

Staufer.-White wine grape resistant to downy mildew. Origin: orig. in Siebeldingen, Germany, at the Institute for Grapevine Breeding Geilweilerhof. Bacchus x Villard Blanc; tested as Gf.Ga-54-14; introd. in 1994. Variety protection in Germany. Fruit: white; large; oval; ripens before Silvaner and after Müller-Thurgau; berry drop can occur during advanced stages of ripening; wines are full-bodied, neutral to fruity with a character ranging between Silvaner and Riesling. Cluster: medium to large; loose. Vine: moderate vigor; yields similar to Müller-Thurgau; good resistance to downy mildew and sufficient resistance to powdery mildew and in general chemical control measures are not needed; wood maturity medium and less winter hardy than Riesling.

Summer Muscat.-A large-fruited, early-ripening, seedless, muscat raisin grape. Origin: orig. in Fresno, Calif., by D.W. Ramming and R. Tarailo, USDA Horticultural Crops Research Laboratory. A4-162 x P100-111; cross made in 1980; sel. in 1984; tested as B1-88; introd. in 1999; not patented. Fruit: white; seedless with one to two aborted seeds which are very small and rarely noticeable; medium (1.4-1.9 g); flavor sweet with a strong muscat flavor that remains when the fruit is dried; soluble solids $22 \%$ and canes can be cut and fruit allowed to dry on the vine; raisin quality similar to Fiesta; medium skin thickness; ripens with Fiesta at Fresno. Cluster: conical with shoulder; loose; large in length but small in weight (113-227 g). Vine: vigorous; a "T" trellis is recommended to spread the fruiting canes and allow more air to circulate to dry fruit on cut canes; productive, averaging 2 clusters per shoot compared to 1.5 for Fiesta; blooms 1-3 days before Fiesta.

Summer Royal.-A midseason, seedless, black table grape. Origin: orig. in Fresno, Calif., by D.W. Ramming and R. Tarailo, USDA Horticultural Crops Research Laboratory. A69-190 x C20-149; cross made in 1985; sel. in 1990; tested as B74-99; introd. in 1999; not patented. Fruit: black with waxy bloom; round to slightly oval; seedless with one to two aborted seeds which are very small and undetectable; medium (naturally 4.3-5.3 g) and responds to gibberellic acid at berry set and with girdling can increase berry weight $1 \mathrm{~g}$; flavor sweet and neutral; quality best when harvested at $18 \%$ soluble solids; nonslipskin and medium skin thickness; ripens mid- season after Fantasy Seedless at Fresno. Cluster: conical with shoulder; slightly loose; medium-large ( $454 \mathrm{~g}$ ); cluster tipping at bloom may be needed on vigorous vines to increase berry set. Vine: medium vigor; production high when cane pruned.

Sunmuscat.-Seedless, muscat, white table grape. Origin: orig in Fresno, Calif., and was originally selected by J.H. Weinberger and F.N. Harmon in Fresno, Calif., and tested in Australia by H.P. Newman and P.R. Clingeleffer. Cooperative release of the USDA and the Commonwealth Scientific and Industrial Research Organisation, Merbein, Australia. Calmeria x P64-18; cross made in 1958; sel. in 1961; tested as Fresno 58-93 or C58-93; introd. in 1999; not patented. Fruit: white; seedless; medium (naturally $2.7 \mathrm{~g}$ ); application of gibberellic acid increased berry size $40 \%$; pleasant muscat flavor remains after drying. Vine: productive in trials in Australia. Not 
recommended for California because of fall rain damage that can result from late maturity and raisin quality not acceptable in California.

\section{JACKFRUIT}

\section{Robert J. Knight, Jr. Univ. of Florida, Tropical Research and Education Center Homestead}

Black Gold.-Deep orange-flesh variety. Origin: Queensland, Australia. Fruit: dark green with sharp, fleshy spines that do not flatten upon maturity, making the proper harvest time difficult to judge and making handling after harvest difficult. Average fruit weight 6.7 $\mathrm{kg}, 35 \%$ edible pulp with 192 seeds per fruit constituting $17 \%$ of total fruit weight. Pulp is deep orange and soft to medium-firm with a strong, sweet flavor and aroma. Flesh is more easily separated from the rag than that of other cultivars. Tree: of medium vigor with a spreading, highly manageable canopy. With annual pruning, easily kept at a height and spread of 2-2.5 $\mathrm{m}$ and a consistent heavy production of $55-90 \mathrm{~kg}$.

Cheena.-Hybrid between Jackfruit and champedak (Artocarpus integer). Origin: Malaysia. Fruit: small, averaging $2.4 \mathrm{~kg}$ weight, are long, narrow, and uniform in size and shape with 38 seeds per fruit ( $11 \%$ of fruit weight), having green skin with blunt spines that yellow and open slightly upon maturity. Edible pulp averages 33\%, is deep orange, soft and fibrous, with excellent flavor. Fruit have an intense aroma, are usually produced one per shoot without thinning, and heavy fruiting does not damage the tree. Pulp is easily separated from the rag, requiring less than 10 minutes to prepare a fruit for consumption. There is little problem with latex in ripe fruit. Tree: open, low, and spreading growth habit; can be kept at a height and spread of $2.5 \mathrm{~m}$ with annual pruning, and consistently produces $50-70 \mathrm{~kg} / \mathrm{tree}$.

Dang Rasimi.-Deep-orange-fleshed variety. Origin: Thailand. Fruit: Fruit are green to pale yellow and uniform in shape if pruned to one fruit per fruiting shoot, are medium to large, averaging $5.7 \mathrm{~kg}$, with $32 \%$ edible pulp and 137 seeds per fruit (12\% of total weight). Skin has sharp spines that do not flatten or open with maturity. Pulp is deep orange and firm, with a mild sweet flavor and a pleasant aroma. This cultivar is well suited to marginal conditions because of its vigor which allows it to stay healthy while fruiting heavily. Tree: open, spreading, and fast growing and must be pruned to keep down to a height and spread of 3-3.5 m. It is vigorous and highly productive, yielding 75$125 \mathrm{~kg} /$ tree.

Golden Nugget.-Deep-orange-fleshed variety. Origin: Queensland, Australia. Fruit: Fruit is small (average weight $3.2 \mathrm{~kg}$ ), green and rounded, with sharp, fleshy spines on the skin that flatten and change to golden yellow upon ripening. Seeds average 79 per fruit, constituting $13 \%$ of the total fruit weight. The deep orange pulp is soft to medium-firm depending upon ripeness, and of an excellent flavor with no fiber. Fruit of this cultivar often split on the tree when exposed to heavy rains. Tree: vigorous, with a distinctive rounded, dark green leaf and a dense, spreading canopy easily maintained at a height and spread of 2-2.5 m. Yields can be maintained at $60-80 \mathrm{~kg} /$ year; fruit should be thinned to $20-25$ per tree to avoid tree damage from overproduction.

Honey Gold.-Deep yellow-fleshed variety. Origin: Queensland, Australia. Fruit: blocky, dark green, and on average weighs $4.5 \mathrm{~kg}$, with small sharp spines that open and turn a golden yellow at maturity. Pulp is dark yellow to orange having a sweet, rich flavor, with an edible portion that amounts to $36 \%$ of fruit weight. Fruit contains 42 seeds which constitute $5 \%$ of its total weight, and has a strong, sweet aroma. Tree: slow to moderate growth rate and forms a small, open and spreading canopy. It can be kept at a height and spread of $2.5 \mathrm{~m}$ with annual pruning and will produce $35-50 \mathrm{~kg}$. Fruit thinning is necessary to maintain healthy growth.

J-30.-Deep-orange fleshed variety. Origin: Malaysia. Fruit: blocky and dark green with small, sharp spines that open and turn golden yellow at maturity; weighs on average $5.6 \mathrm{~kg}$ with $27 \%$ edible pulp. Fruit contains 166 seeds which constitute $9 \%$ of its total weight. Pulp is deep orange and firm although the walls of the flesh are thin, with a rich, sweet flavor and only slight aroma to the pulp and fruit.
Tree: vigorous, with an open, conical canopy and can be maintained at a height and spread of $3 \mathrm{~m}$ with annual pruning. Production is a moderate $50-60 \mathrm{~kg} / \mathrm{year}$, with fruit uniform and hanging singly on the major limbs.

J-31.-Deep yellow-fleshed variety. Origin: Malaysia. Fruit: averages $12 \mathrm{~kg}$ and is irregular in shape, with prominent, blunt spines and edible pulp constituting $36 \%$ of its total weight. The 180 seeds per fruit constitute $18 \%$ of total weight. Pulp is thick-walled, deep yellow and firm, sweet, and rich with a strong, earthy aroma. Tree: forms a small, spreading open canopy and can be kept to a spread and height of $2-2.5 \mathrm{~m}$, at which size it can produce $42-60 \mathrm{~kg} / \mathrm{tree}$ with the required fruit thinning. Often produces off-season fruit during fall and winter.

NS1.-One of the first improved jackfruit cultivars brought to the western hemisphere. Origin: Malaysia. Fruit: blocky and dark green, with blunt spines on the skin that flatten and open at fruit maturity; weighs $4.2 \mathrm{~kg}$ of which $34 \%$ is edible pulp. It contains 63 seeds which constitute $5 \%$ of total fruit weight. Pulp is dark orange and firm, and has a rich, sweet flavor. Tree: medium vigor, forms a dense, upright canopy that can be kept at a height and spread of 2.5-3 m with moderate annual pruning. Annual yields are $90 \mathrm{~kg}$ or more.

Tabouey.-Yellow-fruited variety. Origin: Indonesia. Fruit: long, thin, and tapered at the stem end, often misshapen, with a bright yellow color and irregular, blunt spines. Pulp is firm, pale yellow, with almost no aroma, but has a mild and pleasant flavor. Tree: forms an open, rounded canopy and has rounded, dark green leaves. It can be maintained at a height and spread of $3 \mathrm{~m}$ with annual pruning and produces moderate crops of $50-70 \mathrm{~kg} /$ tree.

\section{NECTARINE}

Jerome L. Frecon

\section{Dept. of Agricultural and Resource Management Agents Rutgers Cooperative Extension} New Brunswick, N.J.

Arctic Belle.-White, low-acid nectarine. Origin: in Modesto, Calif., by C. Floyd, Gary N. and Grant G. Zaiger, and Leith M. Gardner. Introduced in 1997. Open-pollinated seedling of Zaiger 141LB505. USPP 10479 issued on 7 July 1998. Fruit: large; skin is white to yellowish white nearly overspread with red to orient redcolor; flesh firm, white to pinkish white, excellent, mild subacid, sweet; semi- freestone. Ripens 5-12 July in Modesto, Calif., 4-5 days after Arctic Rose (USPP 7889) nectarine. Tree: large; vigorous; upright, productive. Leaf glands reniform. Flowers large; showy; pink; self-fertile.

Arctic Blaze.-White, low-acid nectarine. Origin: in Modesto, Calif., by C. Floyd, Gary N. and Grant G. Zaiger, and Leith M. Gardner. Introduced in 1996. Zaiger 23R236 x Zaiger 63EC404. USPP 10174 issued on 6 Jan. 1998. Fruit: large; nearly globose; skin is white to yellowish white nearly overspread with lake red to garnet red; flesh firm, white to pinkish white, excellent, mild sweet, subacid; clingstone. Ripens 2-8 Aug. in Modesto, Calif., 7-8 days later than Arctic Queen. Tree: large; vigorous; upright; productive. Leaf glands reniform. Flowers large; showy; pink; self-fertile.

Arctic Jay.-White, low-acid nectarine. Origin: in Modesto, Calif., by C. Floyd, Gary N. and Grant G. Zaiger, and Leith M. Gardner. Introduced in 1996. Zaiger 38EB371 x Zaiger 23K46. USPP 9908 issued on 3 June 1997. Fruit: large; globose; skin is white to yellowish white overspread with bronze red; flesh firm, white to milk white, excellent, mild, sweet subacid; freestone. Ripens on 7-13 July in Modesto, Calif., 8 days later than Arctic Rose (USPP 7889). Tree: large; vigorous; upright; productive. Leaf glands reniform. Flowers large; showy; pink; self-fertile.

Arctic Mist.-White low-acid nectarine. Origin: in Modesto, Calif., by C. Floyd, Gary N. and Grant G. Zaiger, and Leith M. Gardner. Introduced in 1997. Open-pollinated seedling of Arctic Snow (USPP 7920). USPP 10919 issued on 25 May 1999. Fruit: large; skin yellowish white to pale yellow, overspread with deep red to strawberry red, flesh white with brownish red to strawberry red pit cavity, firm, sweet, subacid, mild, freestone. Ripens 10-18 Sept. in Modesto, Calif., 9 days later than Arctic Snow. Tree: large; vigorous; upright; productive. Leaf glands reniform. Flowers large; showy; pink; self-fertile. Chilling requirement is $850 \mathrm{~h}$. 
August Pearl.-White, low-acid nectarine. Origin: in LeGrand, Calif., by Lowell Glen Bradford, and Norman G. Bradford. Introduced in 1997. Red Glen (USPP 7193) nectarine x August Snow (USPP 8947) nectarine. USPP 10926 issued on 1 June 1999. Fruit: uniform; large; skin is dark red; flesh yellowish white, very firm, very crisp, subacid and sweet; clingstone. Ripens 9-21 Aug. in LeGrand, Calif., 12 days later than August Snow. Tree: flowers large; showy; self-fertile. Leaf glands globose; alternate. large; vigorous; upright and dense; productive.

Candy White.-White, low-acid nectarine. Origin: in LeGrand, Calif., by Lowell Glen Bradford, and Norman G. Bradford. Introduced in 1997. Ruby Diamond (USPP7918) nectarine X unnamed white nectarine. USPP 10924 issued on 25 May 1999. Fruit: uniform; large; skin is pale purplish pink; flesh greenish white, very firm, tough, crisp, nonmelting, subacid, and very sweet; freestone. Ripens from 20 June to 3 July in LeGrand, Calif., 9 days later than June Pearl. Tree: flowers large, showy; self-fertile. Leaf glands reniform; alternate. medium; medium vigor; spreading and dense; very productive.

Early Juan.- Yellow clingstone nectarine. Origin: in LeGrand, Calif., by Lowell Glen Bradford and Norman G. Bradford. Introduced in 1997. Early Diamond (USPP 5438) nectarine X unnamed seedling. USPP 10908 issued on 18 May 1999. Fruit: uniform; medium; skin is dark red; flesh brilliant yellow; medium firm, acidic with medium sweetness; clingstone. Ripens from 13-25 May in LeGrand, Calif., 1 week earlier than Early Diamond. Tree: flowers large; showy; selffertile. Leaf glands globose; alternate. large; vigorous; spreading and dense; productive.

Fire Sweet.-Yellow low-acid nectarine. Origin: in LeGrand, Calif., by Lowell Glen Bradford and Norman G. Bradford. Introduced in 1996. Summer Fire (USPP 7506) X unnamed nectarine seedling. Issued as USPP 9961 on 15 July 1997. Fruit: medium; uniform; globose to slightly oblong; skin is dark red over a moderate reddish orange color; flesh firm, tough, crisp, brilliant yellow, subacid, very sweet; clingstone. Ripens from 24 July to 8 Aug. in LeGrand, Calif., 6 days later than Summer Fire. Tree: flowers small; nonshowy; moderate purplish red. Leaf glands reniform; opposite. medium; medium vigor; spreading and dense; productive.

Grand Pearl.-White, low-acid nectarine. Origin: in LeGrand, Calif., by Lowell Glen Bradford and Norman G. Bradford. Introduced in 1996. Red Glen (USPP 7193) x June Pearl (USPP 9360). Issued as USPP 9960 on 15 July 1997. Fruit: medium; uniform; globose to ovate; skin is dark red blending to strong red; flesh very firm, crisp, white to pale yellow white, subacid and sweet; clingstone. Ripens 8 17 July in LeGrand, Calif., 4 weeks later than June Pearl. Tree: flowers large, showy, pale purplish pink. Leaf glands reniform; alternate. medium; medium vigor; spreading and dense; productive.

Kay Glo.-Yellow clingstone nectarine. Origin: in Modesto, Calif., by C. Floyd, Gary N. and Grant G. Zaiger, and Leith M. Gardner. Introduced in 1996. Zaiger 46G24 x May Crest (USPP 4064) peach. USPP 10241 issued on 17 Feb. 1998. Fruit: large; uniform; skin is butter yellow to orange yellow overspread with madder red to red color; flesh very firm, light yellow to butter yellow, very good, good balance between acid and sugar; clingstone. Ripens 25-30 May, in Modesto, Calif., 3-4 days before May Grand. Tree: flowers large; showy; self-fertile. Leaf glands globose. large; vigorous; semi-upright; productive.

Kay Pearl.-White, low-acid nectarine. Origin: in LeGrand, Calif., by Lowell Glen Bradford, and Norman G. Bradford. Introduced in 1997. Spring Bright (USPP 7507) nectarine $x$ unnamed white fleshed seedling. USPP 10871 issued on 27 Apr. 1999. Fruit: uniform; large; skin very dark red; flesh greenish white, firm, crisp; eating quality subacid and sweet; freestone. Ripens last week of June in LeGrand, Calif. Tree: flowers large; showy; self-fertile. Leaf glands globose. large; vigorous; spreading and dense; productive.

Kay Sweet.-Yellow, low-acid nectarine. Origin: in LeGrand, Calif., by Lowell Glen Bradford and Norman G. Bradford. Introduced in 1997. Open-pollinated seedling. USPP 10881 issued on 4 May 1999. Fruit: uniform; medium; skin dark red; flesh vivid yellow, firm, crisp, eating quality; sub acid and mildly sweet; clingstone. Ripens 26 May to 6 June in LeGrand, Calif. Tree: Flowers large; showy; selffertile. Leaf glands reniform; alternate. large; spreading and dense, productive.
Regal Red.-Yellow clingstone nectarine. Origin: in LeGrand, Calif., by Lowell Glen Bradford, and Norman G. Bradford. Introduced in 1997. Red Glen (USPP 7193) nectarine x September Red (USPP 5664) nectarine. USPP 10902 issued on 18 May 1999. Fruit: uniform; large; skin; very dark red, flesh brilliant orange-yellow, very firm, acidic with medium sweetness, clingstone. Ripens 28 July to $20 \mathrm{Aug}$. in LeGrand, Calif., 12 days later than Red Glen. Tree: Flowers large; showy; self-fertile. Leaf glands reniform; alternate. large; vigorous; spreading and dense; productive.

Ruby Pearl.-White, low-acid nectarine. Origin: in LeGrand, Calif., by Lowell Glen Bradford and Norman G. Bradford. Introduced in 1996. Red Diamond (USPP 3165) x June Pearl (USPP 9360). USPP 9959 issued on 15 July 1999. Fruit: medium; uniform; globose; skin is very deep red; flesh greenish white, firm, crisp, subacid, sweet; clingstone. Ripens 26 June to 7 July in LeGrand, Calif., 14 days later than June Pearl. Tree: flowers small; nonshowy; light purplish pink. Leaf glands reniform, opposite and alternate. medium; medium vigor; upright and dense; productive.

Ruby Sweet.-Yellow low-acid nectarine. Origin: in LeGrand, Calif., by Lowell Glen Bradford and Norman G. Bradford. Introduced in 1996. Spring Bright (USPP 7505) x June Pearl (USPP 9360). USPP 9963 issued on 15 July 1997 . Fruit: medium; globose; skin is dark red blending into a strong reddish-orange color; flesh firm, crisp, brilliant yellow, mild sweet, subacid; clingstone. Ripens 26 June to 5 July in LeGrand, Calif., 7 days later than Spring Bright. Tree: flowers large; showy; light purplish pink. Leaf glands reniform; alternate. medium; vigorous; upright and dense; productive.

Spring Glo.-Yellow clingstone nectarine. Origin: in Modesto, Calif., by C. Floyd, Gary N. and Grant G. Zaiger, and Leith M. Gardner. Introduced in 1996. Zaiger 31EB232 x Zaiger 94ED118. USPP 10022 issued on 9 Sept. 1997. Fruit: medium; globose; skin yellow overspread with red; flesh firm, light yellow to yellow, good flavor; clingstone; Ripens 21-26 May in Modesto, Calif., 7 days before Mayglo. Tree: flowers large; showy; pink; self-fertile. Leaf glands reniform. large; vigorous; upright; productive. Chilling requirement is $350 \mathrm{~h}$.

Spring Sweet.-Yellow low-acid nectarine. Origin: in LeGrand, Calif., by Lowell Glen Bradford and Norman G. Bradford. Introduced in 1996. Kay Diamond (USPP 8923) x June Pearl (USPP 9360). USPP 9962 issued on 15 July 1999. Fruit: medium; uniform; globose; skin is very deep red over dark orange red color; flesh firm, crisp, brilliant yellow, subacid, sweet; clingstone. Ripens 21-28 June in LeGrand, Calif., 5 days later than Kay Diamond. Tree: Flowers large; showy; pale purplish pink. Leaf glands reniform, alternate medium; medium vigor; spreading; productive.

Western Pride.-Yellow freestone nectarine. Origin: in LeGrand, Calif., by Lowell Glen Bradford and Norman G. Bradford. Introduced in 1997. Unnamed peach $\times$ August Red (USPP 6363) nectarine. USPP 10889 issued on 11 May 1999. Fruit: uniform; large; skin; strong red orange, flesh brilliant yellow, firm, crisp, acidic and sweet; freestone. Ripens on 13-25 July in LeGrand, Calif., 5 days later than Summer Bright nectarine. Tree: Flowers nonshowy; medium; self-fertile. Leaf glands reniform, opposite, large; upright; vigorous; very productive.

\section{PEACH}

\section{Jerome L. Frecon \\ Dept. of Agricultural and Resource Management Agents Rutgers Cooperative Extension New Brunswick, N.J.}

Country Sweet.-Yellow, low-acid peach. Origin: in Modesto, Calif., by C. Floyd, Gary N. and Grant G. Zaiger, and Leith M. Gardner. Introduced in 1998. Zaiger 36EB86 x Zaiger 9GC175. USPP 11090 issued on 12 Oct. 1999. Fruit: large; skin has yellow to golden yellow ground color overspread with light red to orange red color; moderate and medium length pubescence, flesh firm, light yellow to yellow, excellent, mild, sweet, sub-acid flavor; semi-freestone. Ripens 15-21 June in Modesto, Calif., 1 week later than Sweet Gem. Tree: large; vigorous; spreading and dense; productive. Leaf glands reniform. Flowers large; showy; pink; self-fertile. 
Gayla Rich.-Yellow, clingstone peach. Origin: in Modesto, Calif., by C. Floyd, Gary N. and Grant G. Zaiger, and Leith M. Gardner. Introduced in 1996. Earlirich (USPP 9002) x Zaiger 104LB268. USPP 10127 issued on 25 Nov. 1997. Fruit: large; nearly globose; skin is yellow to golden yellow nearly overspread with red to madder red color; moderate and short length pubescence; flesh firm; light yellow to yellow, good, balanced between sugar and acid; clingstone. Ripens 20-26 May in Modesto, Calif., same season as Maycrest. Tree: large; vigorous; upright, productive. Leaf glands reniform. Flowers large, showy; pink; self-fertile.

Klondike White.-White, low-acid peach. Origin: in Modesto, Calif., by C. Floyd, Gary N. and Grant G. Zaiger, and Leith M. Gardner. Introduced in 1997. Zaiger seedling 37G890 x May Crest (USPP 3101). USPP 10872 issued on 27 Apr. 1999. Fruit: large to very large; skin crayfish red to garnet red spread over yellowish white ground color; moderate and short pubescence; flesh firm, white to yellowish white, flavor; mild and sub- acid; freestone. Ripens 25 June to 2 July in Modesto Calif., 2 weeks before Giant Babcock or 1-7 Aug. in New Jersey just after Redhaven. Tree: large; vigorous; upright; productive. Leaf glands globose. Flowers large; showy; pink; selffertile. Chilling requirement $850 \mathrm{~h}$.

Joanna Sweet.-Yellow, low-acid peach. Origin: in Modesto, Calif., by C. Floyd, Gary N. and Grant G. Zaiger, and Leith M. Gardner. Introduced in 1997. Zaiger 55GA106 x Zaiger 33EB323. USPP 10939 issued on 1 June 1999. Fruit: large; skin is pastel yellow overspread with red to strawberry red color; moderate and short pubescence; flesh: very firm, sweet subacid flavor; freestone. Ripens from 3-10 July in Modesto, Calif., 24 days later than Sweet Gem. Tree: large; vigorous; upright and dense; productive. Leaf glands globose. Flowers large; showy; pink; self-fertile.

Prima Gattie.-Yellow, late-season peach. Origin: in Sangor, Calif., by Michael Gerawan. Introduced in 1996. A natural seedling. USPP 10085 issued on 28 Oct. 1999. Fruit: large; uniform; skin color is uneven with a striped to dappled dark red to lighter orange red blush over $30 \%$ off the surface; flesh: very firm, fine, variable light yellow, good; semi-clingstone. Ripens 2-19 Sept. in Sangor, Calif., with the variety Carnival. Tree: variable in size; vigorous; upright to upright spreading; productive. Leaf glands reniform; alternate. Flowers medium to small; nonshowy; light pink.

Sierra Gem.-Yellow, freestone peach. Origin: in Reedley, Calif., by Ron Toews. Introduced in 1997. A chance sport of Fancy Lady (USPP7023). USPP 10810 issued on 2 Mar. 1999. Assigned to The Burchell Nursery, Inc., Oakdale, Calif. Fruit: medium; skin with high degree or barberry red color, medium pubescence; flesh medium-firm, yellow, nonmelting; freestone. Ripens 7 days before Fancy Lady or 12-16 June in the San Joaquin Valley of Central California. Tree: vigorous; upright to spreading; productive. Flowers large, showy; light pink.

Snow Beauty.-White, sub-acid peach. Origin: in Modesto, Calif., by C. Floyd, Gary N. and Grant G. Zaiger, and Leith M. Gardner. Introduced in 1996. Zaiger 30EB280 x Zaiger 1GC131. USPP 10175 issued on 6 Jan. 1998. Fruit: large; skin is white to pinkish red overspread with a red to deep red color; moderate and short pubescence; flesh firm, white to slight pinkish white, excellent, mild, subacid and sweet flavor; freestone. Ripens 21-26 June in Modesto, Calif., 10 days after White Lady. Tree: large; vigorous; upright; productive. Leaf glands reniform. Flowers medium; nonshowy; self-fertile.

Snow Bride.-White, subacid peach. Origin: in Modesto, Calif., by C. Floyd, Gary N. and Grant G. Zaiger, and Leith M. Gardner. Introduced in 1996. Zaiger 22GA1110 X Zaiger 16GA384. USPP 9882 issued on 6 May 1997. Fruit: large; uniform; skin is white to yellowish white overspread with red to geranium red color; moderate, short pubescence; flesh firm, white to oyster shell white, excellent, mild, sweet, subacid; clingstone; Ripens 22-28 July in Modesto, Calif. Tree: large; vigorous; upright; productive. Leaf glands reniform. Flowers medium, nonshowy, pink.

Snow Dance.-White, subacid peach. Origin: in Modesto, Calif., by C. Floyd, Gary N. and Grant G. Zaiger, and Leith M. Gardner. Introduced in 1996. Zaiger 36B85 x Zaiger 5GE8. USPP 9938 issued on 1 July 1997. Fruit: large; globose nearly rounded; skin is white to yellowish white overspread with red to madder red color; moderate and short pubescence; flesh firm white to yellowish white; good, mild, subacid, sweet; clingstone. Ripens 21-26 May in Modesto Calif., 13 days earlier than Sugar May. Tree: large; vigorous; upright; productive. Leaf glands reniform. Flowers large; showy; pink.

Snow Jewel.-White, sub-acid peach. Origin: in Modesto, Calif., by C. Floyd, Gary N. and Grant G. Zaiger, and Leith M. Gardner. Introduced in 1996. Zaiger 20GA1054 x White Lady (USPP 5,821). USPP 10190 issued on 13 Jan. 1998. Fruit: large; skin is white to pinkish white overspread with a red to orient red color; moderate and medium length pubescence; flesh firm, white to pinkish white, excellent, mild, subacid, sweet; clingstone. Ripens 22-26 June in Modesto, 18 days earlier than White Lady. Tree: large, vigorous, upright, productive. Leaf glands reniform. Flowers large; showy; pink; selffertile.

Snow Kist.-White, clingstone peach. Origin: in Modesto, Calif., by C. Floyd, Gary N. and Grant G. Zaiger and Leith M. Gardner. Introduced in 1996. Zaiger 36EB86 x Zaiger 5GB8. USPP 10094 issued on 4 Nov. 1997. Fruit: large; comparatively uniform; nearly globose; skin is white to pinkish white nearly overspread with light red to red blush moderate and medium length pubescence; flesh firm, white to yellowish white, very good flavor; clingstone. Ripens 17-21 May in Modesto, Calif., the same season as Maycrest peach. Tree: large; vigorous; upright; productive. Leaf glands reniform. Flowers large; showy; pink.

Spring Snow.-White, subacid peach. Origin: in Modesto, Calif., by C. Floyd, Gary N. and Grant G. Zaiger, and Leith M. Gardner. Introduced in 1995. Zaiger 47EB280 x Zaiger 1GC131. USPP 9883 issued on 6 May 1997. Fruit: large; comparatively uniform; skin is white to yellowish white overspread with light red to madden red color; moderate and medium pubescence; flesh firm, white to pinkish white, very good, subacid, mild, sweet; clingstone. Ripens 26 May to 1 June in Modesto, Calif., 7 days before Sugar May. Tree: large; vigorous; upright; productive. Leaf glands reniform. Flowers large; showy; pink.

Sweet Dream.-Yellow, subacid peach. Origin: in Modesto, Calif., by C. Floyd, Gary N. and Grant G. Zaiger, and Leith M. Gardner. Introduced in 1996. Believed to be open pollinated seedling of Sweet Gem (USPP 7952). USPP 10176 issued on 6 Jan. 1998. Fruit: large; skin is yellow to golden yellow overspread with a red to crayfish red color; moderate and short pubescence; flesh firm, light yellow to golden yellow, very good, mild, sweet, subacid flavor; clingstone. Ripens 18-24 July in Modesto, Calif., 35 days later than Sweet Gem peach. Tree: large; vigorous; upright; productive. Leaf glands reniform. Flowers large; showy; pink.

Sweet September.-Yellow, subacid peach. Origin: in Modesto, Calif., by C. Floyd, Gary N. and Grant G. Zaiger, and Leith M. Gardner. Introduced in 1996. Zaiger 108ED304 x Zaiger 103ED581. USPP 9964 issued on 15 July 1997. Fruit: large; globose; skin is light yellow to golden yellow with red to coral red exposed to sun; flesh firm, light yellow to yellow, excellent, subacid, mild, sweet. Ripens 12-16 Sept. in Modesto, Calif., 5 days later than O'Henry. Tree: large; vigorous; upright; productive. Leaf glands reniform. Flowers large; showy; pink; self-fertile.

Tuolumne.-Yellow, canning peach. Origin: in Modesto, Calif., by C. Floyd, Gary N. and Grant G. Zaiger, and Leith M. Gardner. Introduced in 1997.Zaiger 57GA963 x Zaiger 14HA602. USPP 10609 issued 22 Sept. 1998. Fruit: medium; skin yellow with very slight red blush, moderate pubescence; flesh very firm, nonmelting, yellow to yellowish orange; good fresh and canned flavor; clingstone. Ripens 4 6 days after Andross or from 29 July 29 to 2 Aug., in Modesto, Calif. Tree: large; vigorous; upright; productive. Leaf glands globose. Flowers medium; nonshowy; self-fertile.

Valley Sweet.-Yellow, subacid peach. Origin: in Modesto, Calif., by C. Floyd, Gary N. and Grant G. Zaiger, and Leith M. Gardner. Introduced in 1997. Zaiger 25GA440 x Zaiger 16RA384. USPP 10387 issued on 12 May 1998. Fruit: large; skin is light yellow to yellow overspread with red to wine red color; flesh firm, light yellow to yellow, very good, sweet, subacid; freestone. Ripens 8-13 July in Modesto, Calif., 10 days before O'Henry peach. Tree: large; vigorous; upright; productive. Leaf glands reniform. Flowers large; showy; self-fertile. 


\section{PECAN}

\section{J. Grauke and Tommy E. Thompson USDA/ARS Pecan Breeding \& Genetics College Station, Tex.}

\section{Alabama Jenkins.-See Jenkins.}

Goose Pond.-Carya illinoinensis selected from Missouri for regular production of good quality nuts in the northern production area. Origin: Native selection made by Paul Manson from Chariton River, 1 mile north from confluence with Missouri River, in Chariton Co., Mo. Original tree was 10-12" dbh when found in the late 1970s while clearing brush and was estimated to be 25 years old. Tree was originally called Duck Pond for proximity to shallow lake constructed for ducks, but was mistakenly entered in local pecan show as Goose Pond, and is propagated under that name. Nut: oblong with prominent, acute beak at apex, acute base, round in cross section; 76 nuts/lb.; $47 \%$ kernel; kernels with dorsal ridge prominently extended beyond kernel lobes, medium dorsal grooves, deep ventral groove and basal cleft; cream in color. Nuts mature in mid-October in Missouri. Tree: relatively slow to break bud in spring; grafts bear in 3-4 years and consistently after.

Hopi._Carya illinoinensis cultivar released 14 May 1999 by USDA-ARS for consistent production of high-quality nuts in the western production area. Origin: Controlled cross (Schley $\times$ McCulley) made by L.D. Romberg in 1939 and tested as selection 39-5-50. Nut: ovate with obtuse apex and rounded base; 46 nuts/lb., 62\% kernel; kernels with distinctively narrow dorsal ridge and relatively narrow dorsal grooves, light cream to cream in color. Neither precocious nor high yielding when compared to Wichita or Western, but comparable to Kanza and Creek. Tree: upright growth habit with strong limb angles; protogynous with mid- to late-season pollen shed and early to midseason pistil receptivity; midseason nut maturity (mid-October in Brownwood, Tex.); resistant to vein spot (Gnomonia nerviseda Cole), moderately susceptible to pecan scab [Cladosporium caryigenum (Ell. et Lang.) Gottwald] and downy spot (Mycosphaerella caryigena Demaree and Cole) diseases; medium susceptibility to yellow aphids (Monelliopsis pecans Bissell) and black aphids (Melanocallis caryaefoliae Davis).

Jenkins (Jenkins 1, Alabama Jenkins).-Seedling selected on the basis of disease resistance and nut quality. Origin: Carya illinoinensis selection of unknown parentage made by Travis Jenkins, Rena Lara, Miss. Tested and cooperatively released by Auburn Univ., Mississippi State Univ., and the Univ. of Georgia. Nut: Ovate, with obtuse, asymmetric apex and rounded base (similar to Success), round in cross section; 55 nuts/lb.; 53\% kernel; kernels with medium dorsal ridge and wide, shallow dorsal grooves. No long term yield data. Tree: incomplete dichogamy; excellent foliage condition and retention in fall; nuts mature 2-3 days before Stuart. Resistant to pecan scab.

Jenkins 1.-See Jenkins.

Martzahn.-Pecan mistakenly propagated as Witte in the Nebraska, Northern Nut Research Orchard, Lincoln, Neb., in 1981 and distributed as Witte until 1998. Origin: Carya illinoinensis seedling from Burlington, Iowa, growing on property of Frank Martzahn. Nut: elliptic with acute apex and acute, often asymmetric, base; 116-163 nuts/lb., $46 \%$ to $53 \%$ kernel; kernels with narrow to medium dorsal grooves, essentially lacking secondary dorsal grooves or basal cleft. Tree: protogynous, with early to midseason receptivity and late pollen shed; extremely early nut maturity, $\approx 3$ weeks before Colby.

\section{PLUM}

\section{David W. Ramming USDA-ARS Horticultural Crops Research Laboratory Fresno, Calif.}

Gulfbeauty.-A low-chill requirement Japanese plum. Origin: Gainesville, Fla., by Wayne B. Sherman. Fourth generation openpollinated seedling descended from Ozark Premier, Burbank, Beauty, and Bruce hybridized with pollen of Taiwan. Taiwan = Huang-ju open-pollinated. Selected in 1985; tested as Fla. 85-1; introduced in 1998. USPPAF. Assigned to Florida Foundation Seed Producers, Inc.
Fruit: small, round; skin dark red; flesh pale yellow; cling; ripe early May in Florida 1 week before Gulfruby. Tree: vigorous, semispreading, cross fertile with Gulfruby, precocious and productive. Tolerant to bacterial spot, high resistance to leaf scald. Chilling requirement $250 \mathrm{~h}$

Gulfblaze.-A low-chill requirement Japanese plum. Origin: In Gainesville, Fla., by Wayne B. Sherman. Fourth generation openpollinated seedling descended from Ozark Premier, Burbank, Beauty, and Bruce hybridized with pollen of Taiwan. Taiwan $=$ Huang-ju open-pollinated. Selected in 1987; tested as Fla. 87-7; introduced in 1998. USPP10873 issued 4 May 1999. Assigned to Florida Foundation Seed Producers, Inc. Fruit: small, round; skin dark red; flesh deep orange; cling; ripe late May in Florida one week after Gulfruby. Tree: vigorous, semi-spreading, cross fertile with Gulfruby, precocious and productive. Tolerant to bacterial spot, high resistance to leaf scald. Chilling requirement $250 \mathrm{~h}$.

\section{RASPBERRY \\ Hugh Daubeny \\ Pacific Agriculture Research Centre Agassiz, B.C., Canada}

AnnaMarie.-A fresh-market, primocane-fruiting raspberry with large fruit, very high productivity, and very good flavor. Origin: Watsonville, Calif., by C.D. Fear and M.M. Mayberry, Sweetbriar Development, Inc.; E39.9 x F164.3; selected in 1993; patented in 1999; USPP 11102. Fruit: large; light red color; good flavor; early primocane crop; midseason floricane crop. Plant: both primocane and floricane yields are very high relative to other cultivars.

Autumn Byrd.-A very early, high-yielding primocane fruiting raspberry that overlaps late-summer fruiting varieties and is released primarily for growing in the Pacific Northwest. Origin: East Malling, England, by V.H. Knight at Horticultural Research International; from a cross made in 1982 by E. Keep between Autumn Bliss and EM 5326/ 1; selected by V.H. Knight in 1985; tested as EM 5961/24; Autumn Byrd is a 3rd backcross from Rubus spectabilis and has inherited genes for early primocane fruiting from this species. Other sources of primocane fruiting genes in its derivation include Lloyd George $(R$. idaeus vulgatus), $R$. $i$. strigosus, $R$. arcticus, and $R$. odoratus. The cultivar also has $R$. crataegifolius and $R$. occidentalis in its derivation. Fruit: medium to large, medium red with downy appearance; moderately firm; easy to harvest; pleasant flavor; some split receptacles; very early primocane fruiting, a week earlier than Autumn Bliss in British Columbia and similar to it in England. Plant: tall, vigorous, fairly erect with short internodes and few spines; higher yield than Autumn Bliss in British Columbia but similar yield in England. Resistant to strains one through four of Amphorophora idaei, the European aphid vector of the raspberry mosaic virus complex; susceptible to the common strain of Amphorophora agathonica, the North American aphid vector of the complex; very slow to become infected with raspberry bushy dwarf virus in the field at East Malling and has not show symptoms of infection; susceptible to Phytophthora fragariae var. rubi in glasshouse tests at East Malling.

Coho.-A high-quality, very late-ripening, floricane-fruiting raspberry suited to both fresh and processing markets. Origin: Corvallis, Ore., by C.E. Finn, F.J. Lawrence, B.C. Strik, and B.Yorey, USDAARS, Oregon. State Univ., Washington State Univ. and Idaho State Univ. Cross of Lewis x ORUS 520-48 (ORUS 1586 x ORUS 1655); selected in 1985; introd. in 1999; tested as ORUS 958-48. Fruit: medium to large, similar to Chilliwack; bright red; excellent firmness, shape, flavor and texture when eaten fresh; late ripening, 4 days after Tulameen; high percentage ( $80 \%$ ) of IQF (individually quick frozen) quality fruit; reported to store and ship well. Plant: very high yields; vigorous but not excessively so; produces moderate numbers of canes with medium thickness; adapted to mechanical harvest. Susceptible to common strain of raspberry bushy dwarf virus; no particular susceptibility to diseases such as Phytophthora fragariae var. rubi; grey mold (Botrytis cinerea) seldom a problem, probably due to late ripening rather than resistance.

Gloria.-A fresh-market, primocane-fruiting raspberry with ex- 
cellent fruit firmness. Origin: Watsonville, Calif., by C.D. Fear and M.M. Mayberry, Sweetbriar Development Inc.; H374 x Summit; selected in 1993; patented in 1999, USPP 11067. Fruit: medium size; bright red; very firm; very early primocane harvest and mid to late floricane harvest. Plant: both primocane and floricane yields are high relative to other cultivars; short cycle tune from plant to harvest of primocane crop.

Godiva.-A yellow, primocane-fruiting raspberry with excellent fruit flavor. Origin: Watsonville, Calif., by S. Wilhelm and C.D. Fear, Sweetbriar Development, Inc.; C96.7 x F167.1; selected in 1990; patented in 1996; USPP 9696. Fruit: medium size; yellow; good firmness; excellent flavor; midseason ripening of both primo- and floricane crops. Plant: high yield relative to other cultivars. Relatively resistant to late leaf rust

Holyoke.-A fresh-market, primocane-fruiting raspberry with large, very attractive fruit. Origin: Watsonville, Calif., by C.D. Fear and M.M. Mayberry, Sweetbriar Development, Inc.; H347.2 x E4.4; selected in 1993; patented in 1999; USPP 11094. Fruit: large; shiny red and does not darken after harvest and storage; very attractive throughout harvest period; early primocane harvest and midseason floricane harvest. Plant: primocane and floricane yields high relative to other cultivars.

Isabel.-A fresh-market, primocane-fruiting raspberry with large, high-quality fruit. Origin: Watsonville, Calif., by S. Wilhelm and C.D. Fear, Sweetbriar Development, Inc.; B36.7 x C44.1; selected in 1989; patented in 1995; USPP 9340. Fruit: large throughout harvest season; red and darkens slightly after harvest; very good flavor; early and lengthy primocane harvest; early floricane crop. Plant: both primocane and floricane yields are high relative to other cultivars. Moderately susceptible to late leaf rust.

Joan J.-An early-ripening, spine-free primocane fruiting raspberry. Origin: Kent, England, by D.L. Jennings, Medway Fruits; Joan Squire $x$ Terri-Louise. World-wide marketing rights held by Meiosis Ltd., East Malling, Kent. Fruit: larger, firmer, and more flavorsome than Autumn Bliss; red color darkens when fully ripe similar to Autumn Bliss. Plant: very vigorous, erect habit, with spine-free canes; strong laterals; higher yield than Autumn Bliss. Susceptible to raspberry bushy dwarf virus.

Tola.-A fresh-market, primocane-fruiting raspberry with excellent fruit firmness, structure and disease resistance. Origin: Watsonville, Calif., by C.D. Fear and M.M. Murray, Sweetbriar Development, Inc.; H374.2 x K589.1; selected in 1992; patented in 1999; USPP 11087. Fruit: medium size and along with shape consistent throughout harvest period; very firm, easy to harvest; early primocane harvest and mid to late floricane harvest. Plant: both primocane and floricane yields are high relative to other cultivars. Relatively resistant to late leaf rust.

Wilhelm.-A fresh-market, primocane-fiuiting raspberry with large, high-quality fruit. Origin: Watsonville, Calif., by S. Wilhelm and C.D. Fear, Sweetbriar Develpment, Inc.; B175.3 x B8.4; selected in 1989; patented in 1996; USSP 9653. Fruit: very attractive; small bright red drupelets with color darkening only slightly after harvest; easy to harvest; both primocane and floricane harvests are midseason relative to other cultivars. Plant: high yield.

\section{STRAWBERRY \\ Chad E. Finn \\ USDA-ARS, Northwest Center for Small Fruit Research Corvallis, Ore.}

ABZ Elan.-An $F_{1}$-hybrid, day-neutral strawberry grown from seed. Origin: Bovenkarspel Holland by Aardbeien uit Zaad B.V. Tested as W78; introd. in 1999. Fruit: medium size (14 g); bi-conical; glossy; bright red skin color; good flesh and skin firmness; uniform size fruit; attractive; excellent flavor. Plant: day-neutral; vigorous. Yields greater than Selva. The time from sowing to fruit production can be controlled under greenhouse conditions and typically ranges from 4 to 6 months. Very susceptible to rain damage and moderately susceptible to powdery mildew (Sphaerotheca macularis).

Ana Maria.-A glossy-fruited, vigorous, partially everbearing strawberry that will continue to re-flower and ripen fruit under cool conditions of central Coastal California. Origin: Monterey County, Calif., by B.D. Mowrey, J.F. Coss, A.Q. Amorao, L.T. Kodama, J.I. Espejo, Jr., T.M. Sjulin, Driscoll Strawberry Associates, Inc., Watsonville, Calif., Key Largo X Q1; selection made in 1993; introd. in 1999. USPP 11035. Fruit: conical; medium-large size (19.6 g); smooth surface; very glossy; dark red; even colored; medium red internal color; aromatic; excellent shelf-life; calyx weakly held on fruit; softer then Key Largo; late ripening. Plant: partially everbearing, will continue to flower and fruit under cool conditions of Coastal California; vigorous; upright; medium to open density. Moderately resistant to high $\mathrm{pH}$, high soil salt levels, drought and high temperatures. Moderately susceptible to Xanthomonas fragariae, Sphaerotheca macularis, and Botrytis fruit rot. Susceptible to injury by Tetranychus urticae, Tarsonemus pallidus, Aphelencoides fragariae, and Lygus hesperus.

Bolero.-A productive day-neutral strawberry with high-quality fruit, adapted for northern Europe. Origin: HRIEast Malling, U.K., by D.W. Simpson. Complex pedigree includes Redgauntlet, Wiltguard, Gorella, Cardinal, and Selva; cross made in 1987; selected in 1988; tested as EMR63; introduced in 1996. Fruit: very regular conical shape; glossy with orange-red color; firm with good flavor and excellent shelf life; medium-large size and low percentage waste; season slightly later than Evita. Plant: day-neutral; vigorous and erect; runner production is better than most other day-neutrals; more productive in trials than Tango and Evita. Pollen production is very good throughout season. Suitable for fresh market, PYO, and home gardens. Moderately resistant to powdery mildew, crown rot (Phytophthora cactorum) and verticillium wilt .

Brunswick.-A midseason, red-stele-resistant strawberry adapted to northeastern North America. Origin: Kentville, Nova Scotia, Canada, by A.R. Jamieson and N.L. Nickerson of the Atlantic Food and Horticulture Research Centre of Agriculture and Agri-Food Canada. Cavendish $\times$ Honeoye; cross made in 1988; selected in 1990; tested as K90-12 and introduced in 1999. Canadian Plant Breeders' Rights (\#0618). Fruit: large (13-14 g from matted rows), larger than Honeoye but slightly smaller than Cavendish; more glossy and more evenly colored than Cavendish; similar in firmness to Cavendish and Honeoye; flavor is good, but rated lower than Cavendish because of higher acidity. Plant: short-day type resembling Cavendish in plant characteristics; producing high yields from matted rows; excellent winter hardiness. Resistant to several races of Phytophthora fragariae; grey mold (Botrytis cinerea) has not been difficult to control; susceptible to powdery mildew, a reaction similar to Honeoye and Cavendish.

Campinas (IAC-2712). - A large-fruited and high-quality cultivar that is well adapted to Brazilian subtropical climate. Origin: Instituto Agronômico (IAC), Campinas, São Paulo State, Brazil, by Dr. Leocádio de Souza Camargo. Donner x Tahoe; cross made in 1955; selected in 1956 as the seedling \#6; released in 1960. Fruit: size, color and firmness similar to Sequoia; fruit shape is a long conic; flavor (sweet/low acidity) and texture (moderately soft) have been the quality standard in São Paulo State since 1960; primarily suited for fresh market but can be processed but not as IQF fruit. Plant: short-day type; ripens early and over an extended period; similar yield to Dover, Oso Grande, Pajaro, and Chandler; vigorous, prolific plant producers. Susceptible to flower blight (Colletotrichum sp.); moderately susceptible to common leaf spot (Mycosphaerella fragariae) and anthracnose crown rot (Colletotrichum acutatum); tolerant to two-spotted mite (Tetranychus telarius).

Cigaline.-An early-ripening, very attractive strawberry with excellent flavor that is adapted to high tunnel production and could replace Gariguette. Origin: CIREF (France), near Bergerac, by P. Roudeillac. Gariguette X Earliglow; cross made in 1989; selected in 1990; tested as CF 89.93.323; introd. in 1996. French plant patent CPOV 12 795; E.C. plant patent 96-1055. Fruit: elongated, conic; more regular that Gariguette; similar size to Gariguette but size more consistent over the season; firmer than Gariguette; orange, nondarkening; very attractive and glossy; good balance between sugar and acidity; very aromatic; ripens early-season; good shelf life for shipping; fresh-market uses; Plant: upright habit; dense foliage; slightly chlorotic leaves; big flowers; good pollen producer; higher 
yields than Gariguette. Tolerant to verticillium wilt and Colletotrichum acutatum; susceptible to Phytophthora cactorum; moderately susceptible to powdery mildew; tolerant to Botrytis cinerea and Marssonina fragariae.

Cigoulette.-A midseason, high-quality strawberry that is adapted to protected culture in temperate climates and shows no symptoms of iron chlorosis on higher $\mathrm{pH}$ soils. Origin: CIREF (France), near Bergerac, by P. Roudeillac.; Belrubi x Pajaro; cross made in 1989; selected in 1990; tested as CF 89.29.266; introd. in 1996. French plant patent CPOV 12793. E.C. plant patent 97-1528. Fruit: conical; regular but skin slightly embossed; large; bright red but darkens slightly; good firmness; flavor better than Pajaro; ripens mid-early season; good shelf life but deteriorates more quickly under warm temperatures; fresh-market uses. Plant: vigorous; globose; very green leaves; leaves slightly blistered; big flowers; medium pollen quality; similar yield to Pajaro; winter hardy in France; no symptoms of iron chlorosis on higher $\mathrm{pH}$ soils. Susceptible to verticillium wilt and Botrytis cinerea; moderately susceptible to powdery mildew; resistant to Phytophthora cactorum; tolerant to Colletotrichum acutatum.

Cijosée.-A day-neutral strawberry with attractive, high-quality fruit that are excellent for shipping and that may replace Seascape in France. Origin: CIREF (France), near Bergerac, by P. Roudeillac. Mara Des Bois X Cal. 18; cross made in 1992; selected in 1993; tested as CF 92-02-1584; introd. in 1997. E.C. plant patent 97-1529. Fruit: conical to globo-conical, very regular during summer and fall; good size but smaller than Seascape; very glossy; bright red, nondarkening; very attractive; good shelf life; juicy; flavor has excellent balance between sweetness and acidity. Plant: more open habit and greater vigor than Seascape; good reblooming and runnering; similar yield to Seascape. Tolerant to verticillium wilt, Phytophthora cactorum, and powdery mildew; intermediate reaction to Colletotrichum acutatum; susceptible to B.L.O. (bacterial-like organism).

Cilady.-A high-quality, midseason strawberry for open-field and small tunnel production for the fresh and processing markets. Origin: CIREF (France), near Bergerac, by P. Roudeillac. Scott x Chandler; cross made in 1989; selected in 1990; tested as CF 89.39.453; introd. in 1996. French plant patent CPOV 13518. E.C. plant patent 99-1173. Fruit: conical to short cuneiform; regular shape; dark green sepals; large size; uniform size throughout season; similar firmness to Pajaro; bright red but darkens; glossy; very attractive; excellent flavor when mature; more sugars and acid than Pajaro; ripens midseason; sometimes spring reblooming; very good shelf life; shipping, fresh-market and processing uses. Plant: globose; similar vigor to Chandler; dark green glossy leaves; needs some chilling; big flowers with good pollen production; high yields, greater than Pajaro; winter hardy in France. Moderately susceptible to verticillium wilt; moderately tolerant to Phytophthora cactorum; very tolerant to Colletotrichum acutatum and Botrytis cinerea; tolerant to powdery mildew.

Ciloé.-A mid-late, cold-hardy, and very productive strawberry for protected culture whose fruit mature slowly and which has excellent shipping ability. Origin: CIREF (France), near Bergerac, by P. Roudeillac. Belrubi X Allstar; cross made in 1989; selected in 1990; tested as CF 89.26.267; introd. in 1996. French plant patent CPOV 13977. E.C. plant patent 96-1052. Fruit: elongated; conical; regular shape; achenes sometimes slightly extend from the surface; brick red but darkens; very large; very high skin firmness; flavor medium to good; ripens mid-late, very good shelf life; shipping and fresh-market uses. Plant: flat, dark green leaves; big flowers with good pollen quality; yield similar to Elsanta; easily picked; slow runnering; seldom exhibits symptoms of winter injury in France. Tolerant to verticillium wilt and powdery mildew; moderate susceptibility to Phytophthora cactorum and to Colletotrichum acutatum; susceptible to Botrytis cinerea.

Cirafine.-A day-neutral strawberry with large, attractive fruit that have excellent flavor for local markets and home gardens. Origin: CIREF (France) near Bergerac, by P. Roudeillac. Mara Des Bois X Cal. 18; cross made in 1992; selected in 1993; tested as CF 92.02.1590; introd. in 1998. E.C. plant patent 97-1533. Fruit: elongated; biconical; regular shape; large to medium size, similar to Seascape; blood red; attractive; achenes sunken; firm fruit but medium shelf life when ripen under warm temperatures; excellent flavor with good sugar/acid balance. Plant: day-neutral; petioles and leaves elongated; good reblooming and runnering; long clusters above the foliage; similar yields to Selva. Tolerant to Phytophthora cactorum; moderately susceptible to verticillium wilt and powdery mildew; susceptible to Colletotrichum acutatum.

Cirano.-A strong day-neutral and disease-resistant strawberry that produces fruit with excellent flavor for fresh-market and home gardens. Origin: CIREF (France), near Bergerac, by P. Roudeillac. Mara Des Bois X Muir; cross made in 1990; selected in 1991; tested as CF 90.40.758; introd. in 1997; E.C. plant patent 97-1530. Fruit: conical to globo-conical; long, narrow sepals; medium to small fruit size, similar to Mara Des Bois; very tough skin; bright red; attractive; very good shelf life; sweet with excellent flavor throughout the picking season. Plant: day-neutral; dark green leaves; good reblooming above the foliage; good runnering; medium vigor. Tolerant to verticillium wilt, Phytophthora cactorum, Colletotrichum acutatum, and powdery mildew .

Cireine.-A midseason, large, and attractive strawberry for protected culture and soilless systems. Origin: CIREF (France), near Bergerac, by P. Roudeillac. Scott x Chandler; cross made in 1989; selected in 1990; tested as CF 89.39.116; introd. in 1996. French plant CPOV 12791. E.C. plant patent 96-1053. Fruit: elongated; biconical; slightly flat; large; good skin firmness; bright red; size consistent throughout season; very glossy and attractive; better flavor than Chandler with good sugar/acid balance; ripens midseason; good shelf life; for shipping and fresh-market uses. Plant: globose, less vigorous and dense than Chandler; big flowers with adequate pollen; upright foliage; similar yield to Pajaro. Susceptible to verticillium wilt and Botrytis cinerea; moderately susceptible to Phytophthora cactorum and powdery mildew

Elkat.-A June-bearing cultivar with medium to large fruit size and high yields that is well adapted to the environmental conditions of Poland. Origin: Research Institute of Pomology and Floriculture, Skierniewice, Poland by E. Zurawicz. Elsanta $x$ Dukat; cross made in 1986; selected in 1988; tested as K-1015 in 1989-93 and later as ISS 494. In 1998, placed in the Polish Register of Cultivated Plants. Fruit: larger than Senga Sengana and similar to Elsanta; slightly less firm than Elsanta; wide conic or globose conic; external and internal color bright red, similar to Elsanta; very glossy; achenes yellow to red and even with the fruit surface or slightly indented; good flavor; high contents of vitamin $\mathrm{C}$; fresh-market, processing and home-garden uses. Plant: June-bearer; greater yield than Elsanta; compact plant with a round growth habit; vigorous. Moderately susceptible to verticillium wilt, resistant to powdery mildew and common leaf spot. Highly tolerant to winter frosts.

Evangeline.-An early-season strawberry with firm fruit, adapted to northeastern North America. Origin: Kentville, Nova Scotia, Canada, by A.R. Jamieson of the Atlantic Food and Horticulture Research Centre of Agriculture and Agri-Food Canada. (Honeoye $X$ Veestar) X NYUS 119; cross made in 1992; selected in 1993; tested as K93-1 and introduced in 1999. Canadian Plant Breeders' Rights (\#0617). Fruit: medium size (10-12 g from matted rows), much larger than Veestar but smaller than Annapolis; berries are uniformly conic with a large calyx; very attractive; color is medium red and the berries are much firmer fleshed than other early season varieties such as Veestar and Annapolis; when fully ripe, the flavor is a rated good to very good with both sugars and acids noted. Plant: short-day type; very stiff, erect flower stalks; flowers with greater-than-average frost sensitivity. Produces medium to high yields from matted rows. Moderately resistant to powdery mildew; susceptible to Phytophthora fragariae; tolerant of grey mold (Botrytis cinerea).

Florence.-A late-season, short-day cultivar with high yield, large berries, and good disease resistance. Origin: HRI East Malling, U.K., by D.W. Simpson. Complex pedigree includes Tioga, Redgauntlet, Wiltguard, Gorella, and Providence; cross made in 1987; selected in 1988; tested as EM372; introduced in 1997. Fruit: larger average fruit size than Elsanta combined with lower percentage waste; ripens seven to 10 days later than Elsanta; regular conical shape; firm skin and flesh; full red color and sweet flavor; good shelf life; suitable for fresh market, PYO and home gardens. Plant: vigorous with erect habit; fruit is well displayed; needs wider spacing than Elsanta; good runner 
production. High yield, particularly from July-planted module (plug) plants. Moderately resistant to powdery mildew and other fungal leaf diseases. Partial resistance to verticillium and crown rot. Tolerant to vine weevil (Otiorhynchus sulcatus).

Granda.-A June-bearing cultivar adapted to the Po Valley environmental conditions, but performing much better in mountain areas (Cuneo-Piemonte Region). Origin: Cesena (Po Valley), Italy, from the public breeding activity of the Italian National Project "Frutticoltura," mainly financed by the Ministry of Agriculture, and coordinated by W. Faedi-Istituto Sperimentale per la FrutticolturaForlì Section. Sel. 83.5.8 x Marmolada ${ }^{\circledR}$ Onebor; cross made in 1989; selected in 1991; tested as 89.250 .1 ; introd. in 1999. Fruit: very large and firm; conic shape; tough skin; bright orange-red color; small achenes are red or yellow and slightly prominent; excellent overall quality; fresh-market uses. Plant: short-day type producing fruit in late season ( $\approx 4$ days later than Marmolada ${ }^{\circ}$ Onebor); very high yield and high vigor; good tolerance to soil borne pathogens and resistant to Colletotrichum acutatum; susceptible to Alternaria alternata and Xanthomonas fragariae.

Guarani (IAC-5074).- - Short-day cultivar developed for processing uses. Origin: Instituto Agronômico (IAC), Campinas, São Paulo State, Brazil, by Dr. Francisco Antonio Passos and Dr. Leocádio de Souza Camargo. (IAC Campinas X IAC Monte Alegre)\#1 x Alemanha; cross made in 1974; selected in 1975 as the seedling \#13; tested as N13 later; released in 1979. Fruit: medium-large; firmer than IAC Campinas; necked conic-long conic; red internal color, darker than IAC Campinas, similar to Chandler; lower soluble solids and higher acidity than IAC Campinas; suited for processing including as IQF fruit. Plant: shortday type producing fruit over an extended period in subtropical climate; production pattern similar to IAC Campinas; compact plant with a moderately erect growth habit. Susceptible to flower blight (Colletotrichum sp.); moderately susceptible to anthracnose crown rot and two-spotted mite (Tetranychus telarius); moderately resistant to common leaf spot (Mycosphaerella fragariae).

IAC-2712.-See Campinas.

IAC-5074.-See Guarani.

IAC-5277.-See Princesa Isabel.

Maya.-A June-bearing cultivar adapted to central northern areas. Origin: Cesena (Po Valley), Italy, by D. Musacchi, G. Raggi, and A. Siboni from New Fruits. Selected in 1992; tested as Sel. 104; introd. in 1998. Fruit: large; elongate conic; uniform, bright red color; achenes are slightly embedded; easily detached; good resistance to handling and transport; fresh-market uses. Plant: short-day type producing fruit in early-midseason, 3 days after Miss and 8 days before Marmolada ${ }^{\circledR}$ Onebor; very high yield; average vigor; good tolerance to the most common fungal diseases such as Oidium fragariae, Sphaerotheca macularis, Mycosphaerella fragariae, and Alternaria alternata.

Mesabi.-A high-yielding, winter hardy, midseason, short-day cultivar adapted to cold climates. Origin: Univ. of Minnesota, by D.K. Wildung, G.J. Galletta, and J.J. Luby. Glooscap x MNUS 99; cross made in 1986; selected in 1988 at Univ. of Minnesota. North Central Research and Outreach Center at Grand Rapids, Minn.; tested as MNUS 248. USPP 111116. Fruit: same maturity season as Glooscap, Kent, Cavendish, and Jewel; similar in size to Glooscap and Kent and smaller than Cavendish and Jewel; flavor is well balanced between sugars and acids with a characteristic strawberry aroma; flesh is moderately firm with a consistent, creamy, melting mouthfeel; skin is glossy and of medium toughness; skin tends to weaken but not darken in hot weather; flesh color is uniform dark red through the fruit except for whitish vascular cylinder; blunt-wedge or blunt-conic shape with large shoulders on primary berries to blunt-conic on the secondary and tertiary berries. Plant: short-day; moderate vigor and runner production; yield has been high, similar to Glooscap. Moderate resistance to leaf spot and powdery mildew and moderate to high resistance to leaf scorch, susceptible to leaf blight. Resistant to 5 eastern North American races of Phytophthora fragariae Hickman (Races A-1, A-2, A-3, A-4, and A-6). Susceptible to iron chlorosis induced by high $\mathrm{pH}$ soils ( $\mathrm{pH} 7.5-$ 8.0) and to black root rot associated with Rhizoctonia spp. and Pythium spp. Very winter tolerant; seldom has exhibited symptoms of winter injury in Minnesota. Good for home garden, u-pick, and on-farm sales.
Onda.-A June-bearing cultivar adapted to the Po Valley environmental conditions, producing large and highly attractive fruits. Origin: in Cesena (Po Valley), Italy, from the public breeding activity of the Italian National Project "Frutticoltura," mainly financed by the Ministry of Agriculture, and coordinated by W. Faedi-Istituto Sperimentale per la Frutticoltura-Forlì Section. Sel. 83.52.1 x Marmolada ${ }^{\circledR}$ Onebor; cross made in 1989; selected in 1991; tested as 89.232.14; introd. in 1998. Fruit: larger and firmer than Marmolada ${ }^{\circledR O n e b o r ; ~ c o n i c ~ s h a p e ~ o r ~ r o u n d e d-c o n i c ; ~ v e r y ~ t o u g h ~ s k i n ; ~}$ orange-red color, brighter than Marmolada ${ }^{\circledR O n e b o r ; ~ s m a l l ~ a c h e n e s ~}$ are red and slightly embedded; medium flavor; fresh-market uses. Plant: short-day type producing fruit in medium-late season; yield similar to Marmolada ${ }^{\circledR}$ Onebor, but needs an earlier planting date; medium vigor; good tolerance to soilborne pathogens, Alternaria alternata and Colletotrichum acutatum; susceptible to Xanthomonas fragariae.

Paros.-A June-bearing cultivar adapted to Central-Southern Italy environments, producing large crops of highly attractive fruits. Paros name is an acronym that Pasquale Rosati used to sign his books and belongings. Origin: Metaponto (Matera), Italy, from the public breeding activity of the Italian National Project "Frutticoltura," mainly financed by the Ministry of Agriculture, and coordinated by W. FaediIstituto Sperimentale per la Frutticoltura-Forlì Section. Marmolada ${ }^{\circledR}$ Onebor X Irvine; cross made in 1989; selected in 1991; tested as 89.384.6; introd. in 1998. Fruit: large and firm; conic shape; very tough skin; orange-red color; very attractive; bright; small achenes are yellow and red, and slightly embedded; medium flavor; freshmarket uses. Plant: short-day type producing fruit in early-medium season, slightly earlier than Pajaro; medium vigor; good tolerance to leaf spot and Alternaria alternata; susceptible to Colletotrichum acutatum, and Xanthomonas fragariae.

Patty.-A June-bearing cultivar adapted to the Po Valley environmental conditions, Verona area in particular, where fall tunnel-protected cultures using large-crowned, cold-stored plants are widespread. Origin: Cesena (Po Valley), Italy, from the public breeding activity of the Italian National Project "Frutticoltura," mainly financed by the Ministry of Agriculture, and coordinated by W. Faedi-Istituto Sperimentale per la Frutticoltura-Forlì Section. Honeoye $\mathrm{x}$ Marmolada ${ }^{\circ}$ Onebor; cross made in 1991; selected in 1993; tested as 91.290.2; introd. in 1999. Fruit: medium-large; moderately firm; conic shape; very regular; medium tough skin; red color that is lighter and brighter than Marmolada®Onebor; small achenes are red or yellow and slightly prominent; medium flavor; fresh-market uses. Plant: short-day type producing fruit in medium-late season; high yield similar to Marmolada®Onebor; medium vigor; good tolerance to soil borne pathogens and Colletotrichum acutatum; susceptible to Xanthomonas fragariae, resistant to powdery mildew. Patty performs well on nonfumigated soils of traditional or organic cultures.

Princesa Isabel (IAC-5277).-—Fresh-market cultivar developed for shipping. Origin: Instituto Agronômico (IAC), by Dr. Francisco Antonio Passos. Alemanha X IAC Jundiaí; cross made in 1981; selected in 1982 as seedling \#10; released in 1989. Fruit: moderately necked; large; long conic; attractive; mild flavor; firmer than IAC Campinas and Sequoia, and similar to IAC Guarani and Reiko. Plant: short-day type producing fruit over an extended period in subtropical climate; production pattern similar to IAC Campinas; vigorous plant; moderately compact; prolific plant producer. Susceptible to common leaf spot and flower blight (Colletotrichum sp.); resistant to anthracnose crown rot and two-spotted mite.

Rebecka.-A Fragaria $X$ vescana hybrid with repeated cropping behavior inherited from the day-neutral strawberry parent Fern. Origin: The Dept. of Horticultural Plant Breeding-Balsgård, Swedish Univ. of Agricultural Sciences, by Karin Trajkovski. (Fern x tetraploid $F$. vesca $) \times(\mathrm{F} 861502)$. Tetraploid $\mathrm{F}$. vesca were produced at Balsgård by doubling the chromosomes of wild plants from the province of Scania in south Sweden; F861502 is a strawberry selection from Balsgård with Lina, Cruz and Honeoye in its pedigree. Rebecka is a decaploid. Cross made in 1991; selected in 1993; tested as 9152003; named and released in 1998. Fruit: medium size; primary fruit are kidney shaped, later fruit are rounder; runners also produce fruit; orange to brick red; somewhat soft; excellent flavor like that of wild 
F. vesca; ripens first crop earlier than Honeoye, repeat crops come very early. Pick your own and home garden uses. Plant: Compact; good winter hardiness; produces small number of strong fruit producing runners. Good resistance to common leaf diseases in Sweden,. Plants available from the Swedish Elite Plant Station.

Rosie.-An early fruiting short-day cultivar with high quality fruit, adapted for growing under protection in northern Europe. Origin: HRI East Malling, U.K. by D.W. Simpson. Honeoye X (Cardinal x [Belrubi x Holiday]); cross made in 1990; selected in 1991; tested as EM575; introduced in 1999. Fruit: very regular conical shape; glossy; strong red color; firm; sweet, aromatic flavor; good shelf life; large size; low percentage waste. Suitable for fresh market. Plant: short-day; moderately vigorous; erect habit; fruit is well displayed; yield similar to Honeoye but season is slightly earlier and more condensed. Good runner production. Susceptible to powdery mildew and verticillium. Early flowering makes frost protection advisable.

Seal.-A June-bearing cultivar with medium size fruit that is well adapted to environmental conditions of Poland. Origin: Research Institute of Pomology and Floriculture, Skierniewice, Poland, by E. Zurawicz. Senga Sengana x Real; cross made in 1984; selected in 1986; tested as K-525 in 1987-93 and later as ISS 194. In 1998, accepted in the Polish Register of Cultivated Plants. Fruit: larger than or similar to Senga Sengana; firmer than Senga Sengana; globose; external and internal color slightly lighter than Senga Sengana; glossy; achenes red and held even with the fruit surface; very good flavor; fresh-market, processing and home-garden uses. Plant: June-bearer; yield similar to or greater than Senga Sengana; compact plant with round growth habit; medium vigor. Moderately susceptible to leaf spot and grey mold, resistant to leaf scorch, powdery mildew and verticillium wilt. High tolerance to winter frosts.

Sophie.-A very late-fruiting, short-day cultivar suitable for the fresh market. Origin: HRI East Malling, U.K., by D.W. Simpson. EM75 (Hapil x Streamliner) x Kent; cross made in 1987; selected in 1988; tested as EM341; introduced in 1997. Fruit: very regular conical shape and dark red color, similar to Honeoye; slightly acidic flavor; moderately firm flesh but skin can be fragile in hot weather; medium large berries (25-35 mm); season equivalent to Pandora, 2 weeks later than Elsanta. Plant: short-day; very vigorous with floppy habit; fruit on long peduncles and easier to harvest than Pandora; prolific runner production. Suitable for fresh market, PYO, and home gardens. Susceptible to powdery mildew and verticillium wilt. Late flowering can result in problems with blossom weevil (Anthonomus rubi).

Tudnew.-A short-day, very productive, large, and firm strawberry that is similar to Chandler and that requires chilling for floral induction. Origin: in Navarra, Spain, by J.M.A Lopez, Plantas de Navarra S.A., Navarra, Spain. Plantas de Navarra selections 85-20 x 86-061; tested as 92.H1.51; introd. in 1999. USPP 10960. Fruit: large size (23-24 g), similar to Oso Grande; long conic; very glossy; uneven fruit surface; firmer than Chandler; medium red flesh and skin; medium sized calyx; early ripening; maintains quality under refrigeration for 48 h. Plant: short-day; flat globose plant habit; medium vigor. Yields similar to Milsei. No particular sensitivity to any disease.

\section{INDEX OF VARIETIES DESCRIBED} (synonyms in italics)

A5510 APPLE

ABZ Elan STRAWBERRY

Adams Apple APPLE

Alabama Jenkins PECAN

Ana Maria STRAWBERRY

AnnaMarie RASPBERRY

Antoneta ALMOND

Apache BLACKBERRY

Arctic Belle NECTARINE

Arctic Blaze NECTARINE

Arctic Jay NECTARINE

Arctic Mist NECTARINE

Ariake CITRUS
August Pearl NECTARINE

Autumn Byrd RASPBERRY

Autumn Gala APPLE

Auvil Early Fuji APPLE

Avalon ALMOND

Black Gold JACKFRUIT

Bolero STRAWBERRY

Bruce CANISTEL

Brunswick STRAWBERRY

Buckeye Gala APPLE (Addendum)

Bull McIntosh APPLE

Burchinal APPLE

Campinas STRAWBERRY

Candy White NECTARINE

Cheena JACKFRUIT

Chickasaw BLACKBERRY

Cigaline STRAWBERRY

Cigoulette STRAWBERRY

Cijosée STRAWBERRY

Cilady STRAWBERRY

Cilo, STRAWBERRY

Cirafine STRAWBERRY

Cirano STRAWBERRY

Cireine STRAWBERRY

Co-op 25 APPLE

Coho RASPBERRY

Country Sweet PEACH

Crown Empire APPLE

Dah Pon CARAMBOLA

Dang Rasimi JACKFRUIT

Del Red Rome APPLE

Dubois 8201 BLACK WALNUT

Early Juan NECTARINE

Elkat STRAWBERRY

Evangeline STRAWBERRY

Fairchild 1 CANISTEL

Fairchild 2 CANISTEL

Fire Sweet NECTARINE

Fitzpatrick CANISTEL

Florence STRAWBERRY

Fuji 216 APPLE

GalaSupreme APPLE (Addendum)

Garden Princess ALMOND

Gayla Rich PEACH

Gloria RASPBERRY

Godiva RASPBERRY

Golden Nugget JACKFRUIT

Goose Pond PECAN

Grand Pearl NECTARINE

Granda STRAWBERRY

Guarani STRAWBERRY

Gulfbeauty PLUM

Gulfblaze PLUM

Harry Black Gala APPLE

Harten Mac APPLE

Holyoke RASPBERRY

Honey Gold JACKFRUIT

Hopi PECAN

HPC-120 BLACK WALNUT

HPC-148 BLACK WALNUT

IAC-2712 STRAWBERRY

IAC-5074 STRAWBERRY

IAC-5277 STRAWBERRY

Isabel RASPBERRY

J-30 JACKFRUIT

J-31 JACKFRUIT

Jenkins PECAN

Jenkins 1 PECAN

Joan J RASPBERRY

Joanna Sweet PEACH

Jupiter GRAPE 
Kahl ALMOND

Kajang CARAMBOLA

Kay Glo NECTARINE

Kay Pearl NECTARINE

Kay Sweet NECTARINE

Kiesau CANISTEL

Kiowa BLACKBERRY (Addendum)

Klondike White PEACH

Kristin CURRANT

LindaMac APPLE

Maha CARAMBOLA

Marquis GRAPE (Addendum)

Marta ALMOND

Martzahn PECAN

Maya STRAWBERRY

McGinnis BLACK WALNUT

Melissa GRAPE

Mesabi STRAWBERRY

Mor CITRUS

Morley ALMOND

Murashige AVOCADO

Nadorcott CITRUS

Narve Viking CURRANT

Ne Plus Ultra ALMOND

Neptune GRAPE

NS1 JACKFRUIT

Onda STRAWBERRY

Orion GRAPE

Paros STRAWBERRY

Patty STRAWBERRY

Peerless ALMOND

Phoenix GRAPE

Prima Gattie PEACH

Princesa Isabel STRAWBERRY

Rebecka STRAWBERRY

Regal Red NECTARINE

Regent GRAPE

Rishon CITRUS

Rosetta ALMOND

Rosie STRAWBERRY

Ross CANISTEL

Ruby Pearl NECTARINE

Ruby Sweet NECTARINE

Rupert BLACK WALNUT

Savana ALMOND

Scarlet O'Hara APPLE

Scarlett GRAPE

Scotian Spur Mac APPLE

Seal STRAWBERRY

Sierra Gem PEACH

Sirius GRAPE

Snapp Stayman APPLE

Snow Beauty PEACH

Snow Bride PEACH

Snow Dance PEACH

Snow Jewel PEACH

Snow Kist PEACH

Sophie STRAWBERRY

Spring Glo NECTARINE

Spring Snow PEACH

Spring Sweet NECTARINE

Sri Kembangan CARAMBOLA

Staufer GRAPE

STW-13 BLACK WALNUT

Summer Muscat GRAPE

Summer Royal GRAPE

Sunmuscat GRAPE

Sweet Dream PEACH

Sweet September PEACH

Tabouey JACKFRUIT

Tean Ma CARAMBOLA
Tex Red Winesap APPLE

Thai Knight CARAMBOLA

Tola RASPBERRY

TREC 9680 CANISTEL

Tudnew STRAWBERRY

Tuolumne PEACH

USDA 1 CANISTEL

USPP 4885 Valenta ALMOND

USPP 5146 Garden Princess ALMOND

USPP 8219 Winola CITRUS

USPP 8236 Rosetta ALMOND

USPP 8269 Morley ALMOND

USPP 8270 Savana ALMOND

USPP 8377 Rishon CITRUS

USPP 8378 Mor CITRUS

USPP 9235 Ariake CITRUS

USPP 9282 Kahl ALMOND

USPP 9340 Isabel RASPBERRY

USPP 9696 Godiva RASPBERRY

USPP 9861 Kiowa BLACKBERRY (Addendum)

USPP 9882 Snow Bride PEACH

USPP 9883 Spring Snow PEACH

USPP 9908 Arctic Jay NECTARINE

USPP 9938 Snow Dance PEACH

USPP 9959 Ruby Pearl NECTARINE

USPP 9960 Grand Pearl NECTARINE

USPP 9961 Fire Sweet NECTARINE

USPP 9962 Spring Sweet NECTARINE

USPP 9963 Ruby Sweet NECTARINE

USPP 9964 Sweet September PEACH

USPP 10010 GalaSupreme APPLE (Addendum)

USPP 10022 Spring Glo NECTARINE

USPP 10070 Scotian Spur Mac APPLE

USPP 10085 Prima Gattie PEACH

USPP 10094 Snow Kist PEACH

USPP 10127 Gayla Rich PEACH

USPP 10141 Auvil Early Fuji APPLE

USPP 10174 Arctic Blaze NECTARINE

USPP 10175 Snow Beauty PEACH

USPP 10176 Sweet Dream PEACH

USPP 10190 Snow Jewel PEACH

USPP 10241 Kay Glo NECTARINE

USPP 10387 Valley Sweet PEACH

USPP 10479 Arctic Belle NECTARINE

USPP 10480 Nadorcott CITRUS

USPP 10609 Tuolumne PEACH

USPP 10810 Sierra Gem PEACH

USPP 10840 Buckeye Gala APPLE (Addendum)

USPP 10871 Kay Pearl NECTARINE

USPP 10872 Klondike White PEACH

USPP 10881 Kay Sweet NECTARINE

USPP 10889 Western Pride NECTARINE

USPP 10902 Regal Red NECTARINE

USPP 10908 Early Juan NECTARINE

USPP 10919 Arctic Mist NECTARINE

USPP 10924 Candy White NECTARINE

USPP 10926 August Pearl NECTARINE

USPP 10939 Joanna Sweet PEACH

USPP 11012 Marquis GRAPE (Addendum)

USPP 11035 Ana Maria STRAWBERRY

USPP 11067 Gloria RASPBERRY

USPP 11071 Snapp Stayman APPLE

USPP 11090 Country Sweet PEACH

USPP 11094 Holyoke RASPBERRY

USPP 11096 Avalon ALMOND

Valenta ALMOND

Valley Sweet PEACH

Western Pride NECTARINE

Wilhelm RASPBERRY

Winola CITRUS

Yamagata AVOCADO 
ADDENDA AND REVISIONS TO PREVIOUS LISTS

APPLE

Buckeye $^{\mathrm{TM}}$ Gala.-Incorrectly stated as ripening 5-7 days earlier than Imperial Gala. Maturity is the same as Imperial, Royal, Gale, Pacific, and other red strains. USPP 10840 issued 1999 (List 39).

GalaSupreme $^{\mathrm{TM}}$ (Davis).—Updated to show corrected spelling (from Galasupreme) and assignment in 1997 of USPP 10010 (List 36).

Myra Red Fuji (Van Leuven).-Correction to show cultivar name and to modify maturity from 3-4 weeks to 5-7 days before standard Fuji (List 39).

\section{BLACKBERRY}

Kiowa._USPP 9861 issued 15 Apr. 1997 (List 38).

\section{GRAPE}

Marquis.-USPP 11012 issued 20 July 1999 to Cornell Research Foundation, Inc. (List 38).

\section{Previous lists:}

List 39 in HortScience 34(2):181-205 (1999).

List 38 in HortScience 32(5):785-805 (1997).

List 37 in HortScience 30(6):1135-1150 (1995).

List 36 in HortScience 29(9):942-969 (1994).

List 35 and earlier lists are included in The Brooks and Olmo Register of Fruit \& Nut Varieties, 3rd ed. (1997), ASHS Press. This book also contains a few previously undescribed varieties that later appeared in Lists 36-38. 